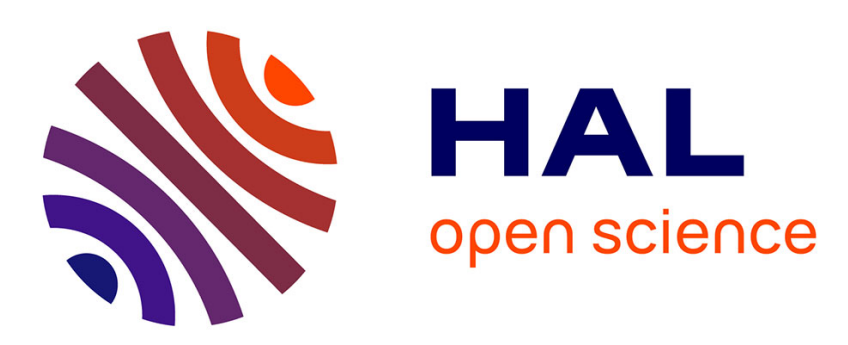

\title{
Corruption and bank risk-taking: The deterring role of Shari'ah supervision
}

Mushtaq Hussain Khan, Mohammad Bitar, Amine Tarazi, Arshad Hassan, Ahmad Fraz

\section{- To cite this version:}

Mushtaq Hussain Khan, Mohammad Bitar, Amine Tarazi, Arshad Hassan, Ahmad Fraz. Corruption and bank risk-taking: The deterring role of Shari'ah supervision. 2021. hal-03366460

\section{HAL Id: hal-03366460 \\ https://hal.science/hal-03366460}

Preprint submitted on 5 Oct 2021

HAL is a multi-disciplinary open access archive for the deposit and dissemination of scientific research documents, whether they are published or not. The documents may come from teaching and research institutions in France or abroad, or from public or private research centers.
L'archive ouverte pluridisciplinaire HAL, est destinée au dépôt et à la diffusion de documents scientifiques de niveau recherche, publiés ou non, émanant des établissements d'enseignement et de recherche français ou étrangers, des laboratoires publics ou privés. 


\title{
Corruption and bank risk-taking: The deterring role of Shari'ah supervision
}

Mushtaq Hussain Khan

Department of Management Sciences, University of Azad Jammu \& Kashmir, Muzaffarabad, Pakistan mushtaq.hussain@ajku.edu.pk

Mohammad Bitar

University of Nottingham Business School, Nottingham, UK

Mohammad.Bitar@nottingham.ac.uk

Amine Tarazi

LAPE, Université de Limoges, Limoges, France

Institut Universitaire de France (IUF), Paris, France

amine.tarazi@unilim.fr

Arshad Hassan

Faculty of Management \& Social Sciences, Capital University of Science \& Technology, Islamabad, Pakistan arshad@cust.edu.pk

Ahmad Fraz

Pakistan Institute of Development Economics, Islamabad, Pakistan

ahmad.fraz@pide.edu.pk

This version: October 4, 2021

\begin{abstract}
This paper investigates whether the risk-taking of Islamic banks is differently affected by corruption compared to conventional banks. Indeed, the presence of Shari' ah supervisory boards (SSBs), as a cornerstone of Islamic banking, is expected to deter the influence of corruption on risk-taking for Islamic banks. We consider a matched sample of 70 Islamic and conventional banks operating in 10 OIC (Organization of Islamic Cooperation) countries over the 2012-2017 period.

We find consistent evidence that higher levels of corruption are associated with higher bank risk for both conventional and Islamic banks. However, this association is stronger for conventional banks. Furthermore, for Islamic banks, the impact of corruption on risk-taking is significantly reduced with higher representation of females in Shari'ah supervisory boards and higher academic qualifications of board members. The role played by such board members in mitigating the impact of corruption on risk-taking is more effective for Islamic banks than for conventional banks.
\end{abstract}

Keywords: Bank risk taking; Corruption; Ethical banking; Shari'ah supervision JEL classification code: O16, G21, G34 


\section{Introduction}

The aim of this paper is to investigate whether corruption differently impacts the risk-taking behavior of Islamic and conventional banks and specifically whether Shari'ah boards play an effective role in moderating such an impact. Although much work has been done in the literature on the role that corruption plays on firms more generally, we know little on how corruption affects banks and specifically their risk which is essential for financial stability. For instance, the corporate finance literature has focused on the association between corruption and firm performance (Van Vu et al., 2018; Brown et al., 2019), corporate innovation (Sena et al., 2018; Gan and Xu, 2019), efficiency (Hanousek et al., 2019), corporate investments (Pan and Tian, 2017), cash holdings (Thakur and Kannadhasan, 2019), credit constraints (Wellalage et al., 2019), and bank lending activity (Bermpei et al., 2020), among others.

Corruption is generally defined as the abuse of public power for private benefit (Aguilera and Vadera, 2008). In addition to bribery and extortion, which defines corruption in a narrow sense, corruption is also manifested in conflicts of interest, fraud, deception, embezzlement, the misuse of government power and other related activities (Gorsira et al., 2018). More importantly, Jim Yong Kim", the president of the World Bank, declared corruption as the "public enemy number one" for most developing economies.

In the specific case of corporate finance, on the one hand, corruption may hinder lending and increase the probability of borrowers' default by raising the cost of debt, but on the other hand, firms with higher productivity and efficiency can bid higher bribes and are more likely to receive more loans (Chen et al., 2015). Evidence from business surveys and empirical studies seems to support the "sand the wheels" hypothesis of corruption according to which corruption is harmful for investment and economic growth. For example, Khwaja and Mian (2005) find that politically connected firms obtain more loans from banks but end up with a higher default rate. Charumilind et al. (2006) find that firms with connections to politicians have better access to long-term bank loans and need less collateral. Park (2012) finds that non-performing loans increase in countries plagued by higher corruption. Likewise, Detragiache et al. (2008) and Weill (2011) find that the growth of lending decreases with severe corruption. Moreover, Chen et al. (2013) find that bribery enables more productive firms to be granted larger loans, consistent with the "grease the

\footnotetext{
${ }^{1}$ See Jim Yong Kim's address at the “Speak Up Against Corruption” event at World Bank on December 19, 2013.
} 
wheels" hypothesis of corruption. Likewise, Williams et al. (2016) and Williams and MartinezPerez (2016) find consistent evidence for the "grease the wheels" hypothesis in developing countries and conclude that bribery constitutes a "helping hand" in terms of firm performance.

In the case of dual banking systems, researchers have focused on comparing conventional banks and Islamic banks with respect to capital structure (Bitar et al., 2018; Bitar and Tarazi, 2019), governance (Mollah and Zaman, 2015), business model (Beck et al., 2013) and risktaking (Abedifar et al., 2013). However, research on how corruption affects the behavior of conventional and Islamic banks is still inexistent. Our paper fills this gap in the context of Islamic banks and conventional banks operating alongside in dual banking systems. We hypothesize that the multi-layer corporate governance model of Shari'ah supervisory boards (SSBs) in Islamic banking and the expected adherence of Islamic banks to ethical behavior (Mollah et al., 2015), which is theoretically the cornerstone of Islamic banks, may contribute to moderate the impact of corruption on bank risk-taking. Our main findings show that the effect of corruption on risk-taking is weaker for Islamic banks than for conventional banks.

Our study also examines whether Islamic banks react differently to corruption depending on (a) the size of SSBs, (b) the presence of females in SSBs, and (c) academic qualification of SSBs members. We expect that the composition of SSBs and their ethical characteristics reduce the effect of corruption on the stability of Islamic banks. In this regard, Choudhury and Alam (2013) document that SSBs are an additional layer of monitoring and oversight as well as a constraint on boards of directors and management from engaging in aggressive lending and major risk-taking activities. Moreover, Mollah and Zaman (2015) argue that at the root of Islamic banking is a theoretical commitment to ethical behavior, a key manifestation of which is the adoption of profit-and-loss sharing schemes and prohibition of interest. Hence, larger SSBs are expected to better monitor for compliance with Islamic ethics and hence moderate the effect of corruption on risk-taking.

There is also an ongoing debate regarding female board representation and its impact on various bank outcomes such as performance and risk-taking. While some studies find a positive relationship between female board of directors and bank risk-taking (Campbell and MinguezVera, 2008; Liu et al., 2014; Post and Byron, 2015; Terjesen et al., 2016), other studies report a negative link (Adams and Ferreira, 2009; Ahern and Dittmar, 2012). Some studies also do not find any link between female as board of directors and bank risk-taking (Carter et al., 2010; 
Chapple and Humphrey, 2014). Moreover, female board representation is expected to alleviate the positive association between corruption and risk-taking because female directorship is a better indicator of a board's independence (Ferreira, 2015). Independent boards can insulate a firm from the detrimental impact of corruption on its performance (Sena et al., 2018).

Academically qualified members may also be valuable monitors and advisors because they add a different perspective, critical thinking, and increase board independence (Francis et al., 2015). They also influence bank risk-taking and performance (King et al., 2016). Specifically, Safiullah and Shamsuddin (2019) investigate the impact of academic qualification of SSB members on bank efficiency and show that board member qualification matters. In line with their findings we argue that SSBs whose members are academically qualified might have better ability to operationalize Islamic principles into banking practices, including enforcement of moral prohibition on excessive risk-taking and unethical practices. For example, advanced academic qualification particularly Ph.D. can enable SSB members to accurately evaluate the risk implications of Shariah-compliant banking and provide guidelines to develop internal techniques for hedging risk.

Our results show that SSB moderates the relationship between corruption and bank risktaking. Particularly, the risk-taking of Islamic banks decreases with higher academic qualifications of SSB members, and higher representation of female members. These findings are robust to a variety of specifications, including the use of alternative measures of corruption and bank risk-taking as well as additional control variables such as institutional environment, national culture, and religiosity. The robustness of our results is also confirmed when we employ an instrumental variables approach (IV), by including 2SLS and GMM estimators to deal with endogeneity concerns.

This study contributes to the literature in two ways. First, it extends the broad literature on risk in Islamic banking (Abedifar et al., 2013; Beck et al., 2013; Mollah et al., 2015; Abedifar et al., 2017; Khan et al., 2020), by investigating how the risk-taking of Islamic banks is differently affected by corruption compared to their conventional counterparts. Specifically, this study examines the role of SSBs as a channel to moderate the effect of corruption on the risk-taking of Islamic banks. Second, we also contribute to the corporate finance literature more generally by highlighting the role played by corporate governance (Dela Rama, 2012; Fu, 2019; Lombardi et 
al., 2019), specifically the presence of female members and academically qualified members in SSBs, in possibly mitigating the negative effects of corruption.

The rest of the paper is organized as follows. Section 2 presents the sample, the variables and the estimation model. Section 3 discusses the main results. Section 4 reports the robustness tests and some further investigations. Section 5 concludes.

\section{Sample and methodology}

\subsection{Construction of the sample and data sources}

We use a sample of 70 Islamic banks and 70 conventional banks operating in 10 OIC (Organization of Islamic Cooperation) countries with dual banking systems where Islamic banks and their conventional counterparts operate alongside each other. Our initial sample includes banks from 15 countries but falls to 10 due a number of restrictions we impose to arrive at our final sample. First, following Mollah et al. (2015), Islamic banks are selected on the basis of their 2010 asset size, date at which we start data collection, and matched with conventional banks based on firm size and country of registration. Second, since the measure of insolvency risk that we use requires the computation of standard deviations, we delete banks that report information for fewer than three consecutive years and run our estimations on a period ranging from 2012 to 2017.

We combine data from several sources. We obtain bank-level financial statements data from the BankScope Financials data file and board structure data from the BankScope Directors data file from 2010 to 2014. For the remaining years (2015 to 2017), we hand-collected data on bank and board structure variables from the web-sites and annual reports of the banks. To ensure accuracy, data on the BankScope classification for Islamic banks are cross-checked with their websites. Moreover, macroeconomic data such as GDP growth, inflation, and oil and mineral rent are taken from the World Bank's World Development Indicators (WDI). Finally, we employ data from the Bank Regulation and Supervision database compiled by the World Bank (Barth et al., 2013; Anginer et al., 2019) to control for institutional environment.

All bank level variables are winsorized at a $1 \%$ tail to mitigate the effect of outliers. Filtering the bank level database and matching it with the country level databases yields a sample of 140 banks with 840 observations in $10 \mathrm{OIC}^{2}$ countries. We use a sample of fully fledged

\footnotetext{
${ }^{2}$ It consists of Bahrain, Bangladesh, Kuwait, Lebanon, Malaysia, Pakistan, Saudi Arabia, Turkey, United Arab Emirates, and Yemen.
} 
Islamic and conventional banks excluding conventional banks with Islamic window. This will help to better understand to what extent the corporate governance of Islamic banks is actually affected by Shari'ah board.

\subsection{Empirical model and variables}

\subsubsection{Baseline model}

In our baseline model we test two hypotheses; "sand the wheels" and "grease the wheels" for both Islamic and conventional banks. The former assumes the detrimental effect of corruption on bank stability whereas the latter considers that although corruption could lead to higher risktaking, if bank profitability is thereby enhanced because of higher or better investment, stability should not be affected. Moreover, we argue that the SSBs in Islamic banking and the expected adherence of Islamic banks to ethical behavior may moderate the effect of corruption on bank risk-taking. To investigate this issue, we add an interaction term between attributes of SSBs and corruption.

We follow Beck et al. (2013), Mollah and Zaman (2015) and Bitar and Tarazi (2019) and use Generalized Least Squares (GLS) confirmed by the Hausman test ${ }^{3}$. The use of GLS technique is more appropriate for two reasons. First, regression models such as OLS ignore the panel structure of our data. Second, the fixed-effects estimator could lead to imprecise estimates when the key regressors do not vary much over time (Semykina and Wooldridge, 2010), pp 326), which corresponds to the corruption index and the Islamic bank dummy variables in our case. We employ the following regression model:

$Y_{i, j, t}=\beta_{0}+\beta_{1}$ Corruption $_{j, t}+\beta_{2}$ Islamic_Dummy $_{i, j, t}+\beta_{3}$ Corruption $_{j, t} \times$ Islamic_Dummy $_{i, j, t}+$ $\beta_{4}$ SSBSZ $_{i, j, t}+\beta_{5}$ Corruption $_{j, t} \times S S B S Z_{i, j, t}+\beta_{6}$ Bank_deter $_{i, j, t}+\beta_{7}$ Country_deter $_{j, t}+$

$\beta_{8}$ Year_Dummies $_{t}+\varepsilon_{i, j, t}$

Where $Y_{i, j, t}$ represents bank risk-taking for bank (i) in country (j) at time (t). Following existing literature, insolvency risk is proxied by the Z-score model (see, e.g., Abedifar et al., 2013; Khan et al., 2017; Mollah et al., 2017, among others). Z-score is defined as [return on assets + equity/assets]/[standard deviation of the return on assets].

Where, standard deviation of the return on assets is computed using a three-year rolling window. Z-score can be interpreted as the number of standard deviations by which returns would

\footnotetext{
${ }^{3}$ Our selection of model is based on the Hausman Test (Fixed versus Random Effects). The null and alternate hypotheses are tested for the choice of model; $\mathrm{H}_{0}$, random effect is more appropriate, $\mathrm{H}_{1}$ : fixed effect is more appropriate. Our results show that the null hypothesis is not rejected; hence the random effects model is used.
} 
have to fall to wipe out all equity of the bank (Roy, 1952), therefore, Z-score can be viewed as the inverse of the probability of bank insolvency. A higher value denotes a higher level of soundness of the bank, or alternatively speaking, a lower value denotes higher exposure to insolvency risk. Because the Z-score is highly skewed, we use the Log values (see, Mollah et al., 2017). Moreover, following Goyeau and Tarazi (1992), Laeven and Levine (2009) and GarcíaSánchez et al. (2017), we break Z-Score into: Leverage risk calculated as[equity/assets]/ standard deviation of the return on asset ; and Portfolio risk computed as [return on assets]/standard deviation of the return on assets.

Corruption $_{j, t}$ is the key independent variable in our investigation. The slope parameter $\beta_{1}$ captures the relationship between corruption and bank risk-taking for conventional banks. The main indicator of corruption which we use is Transparency International's Corruption Perception Index (the TI index, hereafter), which is frequently employed in prior works such as Chen et al. (2015), Jha and Sarangi (2018), Sena et al. (2018), and Sartor and Beamish (2019). The TI index is scaled from 0 to 100 , a higher value indicating less corruption perceived in the country. For a higher value of the TI index to indicate higher corruption, we rescale it by deducting it from 100. The outcome is denoted CI defined as:

$C I=100-T I$ index

Islamic Dummy ${ }_{i, j, t}$ is a dummy variable that takes the value one if the bank is an Islamic bank and zero otherwise. It controls for the difference in bank risk-taking between Islamic and conventional banks. Corruption $_{j, t} \times$ Islamic Dummy $_{i, j, t}$ is the interaction term and our variable of interest. The coefficient $\beta_{3}$ shows whether the relationship between corruption and bank risk-taking is significantly different for Islamic banks compared to their conventional counterparts.

SSB size (SSBSZ) is the Log of the total number of SSB members of an Islamic bank at the end of each year (Farag et al., 2018; Nawaz, 2019). The coefficient of the interaction term $\left(\beta_{5}\right)$ indicates whether SSB size moderates the relationship between corruption and bank risk-taking. Particularly, a positive association of the interaction term with Z-score (an inverse measure of insolvency risk) can be attributed to the strong role of the SSB in advising the bank management and hence in avoiding risky and speculative activities.

Bank_deter $_{i, j, t}$ is a vector of bank-level determinants of risk-taking identified by the traditional banking and corporate finance literature (Abedifar et al., 2013; Kabir et al., 2015; 
Palvia et al., 2015; Bostandzic and Weiss, 2018). These variables include; logarithm of total assets (bank size), equity capital to total assets (capital ratio), percentage growth in total assets in each year (assets growth), cost to income ratio (cost inefficiency), and share of non-interest income in total operating income (non-interest income, NII).

Country_deter $r_{j, t}$ is a vector of macroeconomic and institutional variables that are commonly used in the bank risk taking literature (Barth et al., 2009; Karimalis and Nomikos, 2018; Anginer et al., 2018; Fratzscher and Rieth, 2019; Mourouzidou-Damtsa et al., 2019; Bitar et al., 2020). The country-level variables control for difference in economic conditions and capture the impact of macroeconomic variables on bank risk-taking. We consider GDP growth rate (GDP growth), inflation rate (inflation), and natural resources, i.e. oil rents (oil) and mineral rent (mineral).

The set of institutional variables include supervisory power, deposit insurance, and entry barrier. The variable supervisory power is an index measuring supervisory agencies' power and authority to take specific preventive and corrective actions. The measure ranges from zero to fourteen, with fourteen indicating the highest power of the supervisory agencies. The measure is computed using the responses to 14 questions. The variable entry barrier measures the stringency of entry requirements into the banking industry. It is an index constructed on the basis of 8 questions. The deposit insurance variable indicates whether a country has explicit deposit insurance $(\mathrm{Yes}=1 / \mathrm{No}=0)$ and whether depositors were fully compensated the last time a bank failed $(\mathrm{Yes}=1 / \mathrm{No}=0)$. Existence and strength of deposit insurance provide a proxy for private monitoring incentives. The variable ranges from 0 to 2 , with higher values denoting greater moral hazard and lower private monitoring incentives. All three variables are constructed on the basis of relevant questions documented in existing studies (see Barth et al., 2009; Anginer et al., 2018, among others) by adding a value of 1 to each index if the answer is yes.

In order to control for all country fixed effects, we use country dummy variables in our regression specifications. Moreover, we include year dummies to control for general market conditions. Finally, we follow Beck et al. (2013) and Bitar et al. (2019) and cluster at the bank level, instead of the country level, for two reasons. First, some countries have a much larger number of observations than other countries in the sample. Second, we have ten countries. Therefore, clustering at the country level might create biased results.

\subsubsection{The effect of corruption on bank risk-taking: moderating role of other SSB attributes}


In this section, as a robustness test, we investigate the moderating role of two other SSB attributes; female's representation in SSBs and academic qualification of SSB members on the relationship between corruption on bank risk-taking. To investigate this issue, we add the interaction terms between attributes of SSBs and corruption for a sample of Islamic banks. Particularly, we use the following regression specification:

$Y_{i, j, t}=\beta_{0}+\beta_{1}$ Corruption $_{j, t}+\beta_{2} \operatorname{SSBSZ}_{i, j, t}+\beta_{3} \operatorname{SSBACQ}_{i, j, t}+\beta_{4} \operatorname{SSBFR}_{i, j, t}+\beta_{5}$ Corruption $_{j, t} \times$

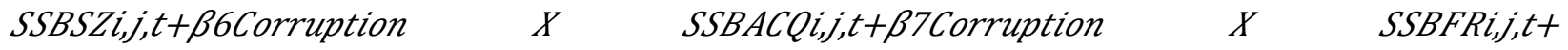
$\beta_{8}$ Bank_Control $_{i, j, t}+\beta_{9}$ Country_Control $_{j, t}+\beta_{10}$ Year_Dummies $_{t}+$

Where $Y_{i, j, t}$ represents bank risk-taking 3 for bank (i) in country (j) at time (t), as discussed in Section 2.2.1. $\operatorname{SSBACQ}_{\mathrm{i}, \mathrm{j}, \mathrm{t}}$, and $\operatorname{SSBFR}_{\mathrm{i}, \mathrm{j}, \mathrm{t}}$ are SSBs members' academic qualifications and representation of females in SSBs in bank (i) in country (j) at time (t). Moreover, female ratio is used as a measure of females' representation in the boards of conventional banks (Sila et al., 2016; Fan et al., 2019). We follow the same analogy for Islamic banks and use the female ratio (number of female members divided by total number of members in SSBs) as proxy of female's representation in SSBs (SSBFR). Finally, academic qualification of SSB members refers to the number of SSB members with doctorate degrees, as a percentage of the total SSB members $(S S B A C Q)^{4}$. The coefficients of interaction terms $\left(\gamma_{5}\right.$ to $\left.\gamma_{7}\right)$ indicate whether attributes of SSBs moderate the relationship between corruption and bank risk-taking.

\subsection{Summary statistics}

Table 1 presents the descriptive statistics for the 10 countries for the risk-taking, the corruption, the bank-level variables and the country-level variables. T-Stat. of mean equality test, shown in Panel A, describes the mean difference in the risk taking between Islamic and conventional banks. The mean test results show that Islamic banks are more stable (alternatively speaking, have lower insolvency risk) than conventional counterparts. Moreover, the summary statistics for the sample of Islamic banks show that, on average, Islamic banks have five members in their SSBs, and 54\% of SSBs members have a doctorate degree. We also observe that, on average, merely $9 \%$ of the SSBs members are female with the highest percentage in Malaysia. The highest percentage of female on SSBs in Malaysia could be due to following reasons. Malaysia is

\footnotetext{
${ }^{4}$ This study follows Berger et al. (2014) and Safiullah et al. (2019) by including doctorate degrees as a measure of academic qualifications since other undergraduate and postgraduate qualifications are typically nested within a doctorate degree.
} 
considered as the hub of Islamic banking and finance in South Asia, as a result of liberalization of their market (Pok, 2012). This liberalism leads to less conservatism towards women in boardrooms of Islamic banks and is thus more likely to promote women to higher executive positions. Moreover, the Malaysian Government encourages the presence of females in the top management of firms. To increase the pool of women who can serve on the boards of Malaysian listed firms, the Government allocated a total of RM10 million (USD 3.3 million) budget in 2012 (Razak, 2011).

We also report mean values of the variables country by country in Panel B. The sampled countries show variations in the level of corruption. For instance, our corruption index $C I$, ranges from a minimum value of 31.00 in UAE to a maximum value of 82.00 in Yemen. The macroeconomic control variables, namely GDP growth, inflation, oil and mineral rents, also significantly vary across countries, indicating that these variables should be controlled for. Finally, Table A.1 in appendix A reports the number of Islamic and conventional banks in each country while Table A.2 reports the pairwise correlation of variables that enter our regression. We notice that for the studied period, the largest number of observations is from Malaysia that is $20 \%$ of the overall sample and the lowest from Lebanon that is $3 \%$. The correlation matrix (Table A.2) does not reveal any major multicollinearity problems between our exogenous variables.

\section{[Insert Table 1 about here]}

\section{Main findings}

We begin by investigating the impact of corruption on bank risk for the sample of conventional banks, the sample of Islamic banks and for the full sample. Table 2 presents the results. In our baseline estimation, we test the impact of corruption on bank risk taking where we use Z-score as a measure of insolvency risk. In the next step, we include corruption and SSB size (SSBSZ), the proxy for Shari'ah supervision and their interaction. For the measurement of a corrupt environment, we employ the original Corruption Perception Index (CI) of the Transparency International.

For the sample of Islamic banks, model (3) and (4), the coefficient of the corruption indicator is negatively associated with Z-score at the $10 \%$ and 5\%, respectively. Likewise, we 
find a significantly negative association of the corruption indicator and Z-score for conventional banks in model (5) and (6) although at the 10\% significance level only. These results suggest that corruption impedes the stability of both Islamic and conventional banks and they face higher insolvency risk in a corrupt environment. Moreover, the results for the full sample (models (1) and (2)) are in line with such findings. However, the detrimental impact of corruption on bank stability appears to be weaker for Islamic banks $\left(\beta_{1}+\beta_{3}\right)$ compared to conventional banks $\left(\beta_{1}\right)$, in Panel B. This could be due to the role of the SSB which to some extent is expected to mitigate unethical behavior (Abdelsalam et al., 2016; Alsaadi et al., 2017; Salem et al., 2021). The results confirm such a conjecture when interacting SSB size (SSBSZ) with the corruption index which shows that SSB size also attenuates the negative effect of corruption on the stability of Islamic banks (Panel C, Models (1) to (4)). On the whole, our findings are in-line with the "sand the wheels" effect of corruption, and not the "grease the wheels" impact of corruption (Joseph et al., 2016; Blanc et al., 2019; Chantziaras et al., 2020).

Furthermore, we include the two components of Z-score; Leverage risk and Portfolio risk to further refine our findings. Models (7) to (18) report the results for the two components of $Z$ score. Although with lower significance level, the results in models (7) to (12), where the dependent variable is Leverage risk (and in models (13) to (18) where the dependent variable is Portfolio risk) are similar to the findings obtained for the Z-score variable. In the case of leverage risk, the coefficient of corruption is significant and negative in all regressions suggesting that depending on the degree of corruption in the economic environment both Islamic and conventional banks take similar decisions regarding how much capital they should hold. However, the coefficients of the corruption variable are slightly lower for Islamic banks than for conventional banks in line with the results obtained with the Z-score. Islamic banks might hence be less affected by corruption because corruption might be affecting their willingness to hold a given amount of capital to a lesser extent. The results regarding portfolio risk are also consistent with those of the Z-scores. As a whole, corruption impacts bank behavior both in terms of how much risk or bad lending they are encouraged to take and in terms of how much capital they hold. The difference in terms of sensitivity of stability (Z-score) to corruption among Islamic banks and conventional banks appears to be driven by both dimensions (capital and risk-taking).

Among the control variables, the results show a positive relationship between size and Zscore, which is consistent with possible diversification benefits. The results also show that less 
efficient banks face higher insolvency risk. As for country-level control variables, we find that banks are more stable and less vulnerable in countries with better GDP growth and stronger institutional environment. In line with the literature (Anginer et al., 2014), our results show that the presence of an explicit deposit insurance system with implicit full coverage is detrimental for bank stability.

\section{[Insert Table 2 about here]}

To go deeper in our investigation, we introduce two attributes of SSBs: female's representation in SSBs (SSBFR) and academic qualification of SSBs members (SSBACQ). The results are reported in Panel A of Table 3 and show that the coefficients of SSBFR and SSBACQ and their interaction with corruption are positive and statistically significant. This implies that the structure of SSBs and specifically the presence of female members and that of academically qualified members enhance bank stability and outweigh the adverse impact of corruption. Such findings are supported by the arguments of the agency theory. Indeed, several studies based on agency theory report that female directors are more likely to be independent (Adams et al., 2009; Dang et al., 2014). Hence, the monitoring role of females on the SSBs might be augmented by their greater independence compared to their male counterparts. Furthermore, according to resource dependency theory, female directors can bring unique and valuable resources and relationships to their boards. The proponents of resource dependency theory argue that the new skills and perspectives brought by female directors to the board result in provision of valuable advice to top managers (Anderson et al., 2011), better decisions related to problem-solving (Daily and Dalton, 2003), enhancement of creativity and innovation (Robinson and Dechant, 1997), and improvement of access to information (Beckman and Haunschild, 2002).

The presence of female as SSB members may represent an inclusive culture of Islamic banks; hence, one can expect a positive relationship between the presence of female in SSBs and stability of Islamic banks. Similarly, SSB members with higher academic qualifications and specifically members having Islamic financial education significantly contribute to lower risk of Islamic banks and improve their stability. There might be several factors explaining the positive impact of board members academic qualification on bank stability. For instance, consistent with the resource-based view, qualified board members are considered as assets and bring diversity on boards in terms of knowledge, expertise, skills and cognition abilities (Anderson et al., 2011; 
Guney et al., 2020). Besides, qualified board members provide relevant professional advice that lowers credit risk, limits negative returns and decreases the chance of bankruptcy (Abdelbadie and Salama, 2019). Academic qualification could also influence the ability of directors to better interpret and evaluate sophisticated risk measurement techniques and the impact of bank policies on risk (Srivastav and Hagendorff, 2016).

In columns (3) to (6), the results regarding the two components of Z-score are reported. Specifically, Leverage risk is used as the dependent variable in models (3) and (4) and Portfolio risk in models (5) and (6). The results show that both SSBFR and SSBACQ seem to be effective resources to reduce insolvency risk for both components of Z-score.

\section{[Insert Table 3 about here]}

We also separately estimate the models for board structure of conventional banks and its interaction with corruption. Indeed, better governance arrangements could also mitigate the impact of corruption for conventional banks. We consider the same board structure variables that are used in the banking (Faleye and Krishnan, 2017; García-Sánchez et al., 2017) and corporate finance (Carter et al., 2010; Sila et al., 2016; Green and Homroy, 2018) literatures. Particularly, board structure of conventional banks include: logarithm of number of directors on board (board size), a dummy variable that takes value one if the CEO is also the chairman of the board, and zero otherwise (CEO duality), number of female directors divided by total number of directors (female ratio), and dummy variables which take the value one if the auditing committee is independent and there is a separate risk management committee in the board structure, respectively.

Results are presented in Table 4. Our results show that stronger and better governance structure has no influence on the impact of corruption in conventional banks. Specifically, when significance of the coefficients of the interaction terms of corruption with female board representation and academically qualified members show merely the $10 \%$ level. This suggests that even with strong governance the impact of corruption is not actually mitigated. This finding underscores the necessity of SSBs, a multi-layer corporate governance model to further reduce the impact of corruption for conventional banks. Besides, other factors such as weak disclosure 
and corporate social responsibility (CSR) practices as well as political connections of board members with corrupt government bureaucrats lead to corrupt environment in MENA and South East Asia. In this regard, Elamer et al. (2020) argue that MENA countries face weak governance structures and poor disclosure practices. Moreover, CSR practices considered as an administrative tool which legitimize the unethical activities such as corruption (Lee, Yoon, \& O'Donnell, 2018; Chantziaras et al., 2020).

\section{[Insert Table 4 about here]}

\section{Further investigations and robustness tests}

In this section, we conduct further investigations and robustness tests using alternative measures of risk and corruption as well as additional control variables. Moreover, alternative econometric methodologies are used for estimations to address potential endogeneity issues.

\subsection{Alternative measures of bank risk}

We now focus on whether our findings persist when we re-estimate our regressions using alternative proxies for bank risk. Specifically, we use three different measures of bank credit risk, namely the ratio of loan-loss reserves to gross loans ( $L L R S)$, ratio of non-performing loans to gross loans (NPLs) and the ratio of loan-loss provisions to average gross loans (LLPS). LLRs represent manager's assessment of the quality of the loan portfolio, including performing and non-performing loans. LLRs takes into account the past performance and the expectation for future performance of the existing loan portfolio (Abedifar et al., 2013). Moreover, its periodic adjustment is reflected in the income statement in the form of loan-loss provision. Therefore, the LLPs and NPLs both backward-looking proxies for credit risk are also used. These three proxies are widely used in the literature as accounting-based credit risk indicators (for example, Sila et al., 2016; Abedifar et al., 2017; Bitar et al., 2020).

Table 5 exhibits the results for credit risk where we use LLRS as the credit risk measure. We find that estimation results are qualitatively unchanged for credit risk. For the sample of conventional banks, model (5) and (6), we find that the coefficient on the corruption indicator is positive and statistically significant. When we use the sample of Islamic banks from model (3) and (4), we find that the coefficient of the corruption indicator is again positive and statistically 
significant. Importantly, the finding of lower coefficients for Islamic banks suggesting that Islamic banks have less exposure to credit risk compared to conventional banks is in line with existing literature (Abedifar et al. 2013). There are a number of reasons why Islamic banks may face lower credit risk than conventional banks. First, Islamic banks normally attract religious people who would less likely default (Abedifar et al., 2013; Baele et al., 2014; Bitar et al., 2019). Second, profit and loss sharing modes of financing may to some extent mitigate adverse selection issues by reducing information asymmetry (Safiullah and Shamsuddin, 2018). Moreover, NPLs and LLPs in lieu of LLRs show similar results for corruption indicators, SSBs attributes and the interaction terms.

\section{[Insert Table 5 about here]}

\subsection{Alternative measures of corruption}

As an alternative corruption indicator and to check the robustness, we include the adjusted Corruption Perception Index (Adj. CI) which reflects the severity of corruption in a country relative to its global average. In case of Corruption Perception Index if a country's score in CI increased from last year, it could have been driven not necessarily by a deteriorated perception of this country's corruption, but by the changing number of surveys or the methodology adopted by Transparency International (Lambsdorff, 2008). Although the change is usually minor and would be less likely to cause a significant variation in a country's corruption index, an adjusted CI index to overcome (at least partially) this biased effect is needed (DeBacker et al., 2015; Chen et al., 2015). We consider the CI index in country $j$ in year $t$ divided by the mean of CI indices across all countries each year denote the outcome as Adj. CI:

$$
\text { Adj. CI }=\frac{C I_{j t}}{\left(\sum_{j=1}^{N} C I_{j t}\right) / N}
$$

Moreover, for an alternative indicator of corruption rather than Transparency International's Corruption Perception Index, we also obtained data from the World Bank's Worldwide Governance Indicators (WGI) and use its sub-index of Control of Corruption (CCI), which is also a commonly adopted indicator of corruption in the related literature (Kaufmann et al., 2010). Scaled from -2.5 to 2.5 , a higher value in CCI indicates less corruption. Borrowing the idea from Chen et al. (2015), we subtracted CCI from 0, thus a higher value in the adjusted CCI denotes 
more severe corruption and the outcome is denoted as WBCI. Results are reported in Table 6 and these results are similar to the ones obtained with the main corruption indicator.

\section{[Insert Table 6 about here]}

\subsection{Additional control variables}

In this subsection, we address the issue of potential omitted variables bias. Therefore, in addition to bank level and macroeconomic variables, we include the institutional environment, national culture and religiosity as additional control variables to further check the robustness of the results. The institutional factors are widely used in the bank risk taking literature (Houston et al., 2010; Agoraki et al., 2011; Anginer et al., 2014; Anginer et al., 2018; Anginer et al., 2019, among others). The institutional variables include creditor rights and components of the economic freedom index (judicial effectiveness, monetary freedom and financial freedom). Stronger creditors' rights grant more power to creditors in case of bankruptcy reducing both the adverse selection and moral hazard problems associated with bank lending. Greater economic freedom is also expected to improve bank stability because banks have a greater array of investment opportunities which could lead to better diversification and superior risk-return combinations. Alternatively, higher competition induced by higher economic freedom could encourage banks to select riskier projects to maintain their profitability. We use the creditor rights index developed by Djankov et al. (2007) to measure the creditor rights across countries. Recent studies have also used the same creditor rights index which is equal to the sum of four binary indicator variables (Gu et al., 2018; Bitar et al., 2019). This index ranges from 0 (weak creditor rights) to 4 (strong creditor rights). Moreover, data on components of economic freedom index is obtained from the website of The Heritage Foundation.

Some studies consider cultural dimensions developed by Hofstede $(1980,2001)$ to explore whether differences between countries due to cultural values such as individualism (IDV), power distance (PDI), masculinity vs. femininity (MAS), and uncertainty avoidance (UAI) impact the risk-taking of financial institutions, such as banks (Ashraf et al., 2016; Ashraf and Arshad, 2017; Boubakri et al., 2017; Mourouzidou-Damtsa et al., 2019; Bitar et al., 2020; Berger et al., 2021), non-financial firms ( $\mathrm{Li}$ et al., 2013), and insurance companies (Gaganis et al., 2019). We also consider these cultural values as additional country-level control variables. 
Finally, our sample contains Muslim countries and therefore it is important to control for the effect of religiosity (the share of the Muslim population in each country) because Shari'ah law is based on religious doctrine. The extant literature argues that religiosity increases the ethical behavior and levels of risk aversion of firms (Kanagaretnam et al., 2015; Blau, 2017; Cai et al., 2020). Moreover, banks in more religious areas exhibit lower risk (Adhikari and Agrawal, 2016; Chircop et al., 2017), and stronger religiosity is also associated with lower loan interest spread (Chen et al., 2016). The data on religiosity is obtained from the websites of Pew Research Center (2015), the global economy.com, The Cline Center for Democracy, and survey reports published by each country. Table 7 reports the results using additional control variables. As for as the additional control variables are concerned, the coefficients of creditor rights and economic freedom are significant and positive suggesting that stronger creditor rights and economic freedom help reducing insolvency risk and hence improve bank stability.

\section{[Insert Table 7 about here]}

In the case of cultural dimensions, our main findings are as follows. We find that the coefficients of $I D V, P D I$ and $M A S$ are significant and negative implying that the individualist countries take on more risk leading to lower stability than in collectivist countries. Because managers in individualist cultures tend to believe that their abilities are above average, which may result in overconfidence (Berger et al., 2021) they are prone to take on more risk. The power distance is linked with the centralization of the authority thereby managers in high power distance societies may have incentives to pursue their personal goals rather than optimizing bank performance (Kanagaretnam et al., 2011). Likewise, our sampled countries are masculine societies and bank managers in masculine societies may be more likely to engage in managing earnings than control risk (Kanagaretnam, et al., 2011) thereby impeding bank stability. Conversely, the coefficient of (UAI) is significant and positive as expected.

Overall, the main findings remain unchanged. The impact of corruption on stability is weaker for Islamic banks than for conventional banks.

\subsection{Endogeneity concerns}


The results presented in the preceding sections provide significant evidence that higher levels of corruption increase risk taking of both types of banks. However, one might argue that this effect might be due to endogeneity concerns. While we have included an array of control variables to the extent that we have not considered institutional features (e.g., regulatory quality) that affect corruption, bank risk taking and performance, there could be correlated omitted variables. Chen et al. (2015) identify regulatory quality as an instrumental variable to investigate the link between corruption and bank risk-taking. They argue that it might be the prevailing riskproneness in the economy, as reflected in a typical bank's risk-taking behavior that determines the pervasion of corrupt transactions. In order to investigate the exogenous effect of corruption, we use the regulatory quality variable to instrument for the corruption indicator. The data for our instrumental variable regulatory quality is obtained from the World Bank's Worldwide Governance Indicators (see, Kaufmann et al., 2010). This variable captures the ability of the government to formulate and implement sound policies and regulations that permit and promote the private sector development. In a more corrupt economy, the government may have a lower incentive to decree more private-sector-friendly policies in order to pursue higher rent-seeking interests. However, governments' ability to formulate and implement proper policies is less likely related to banks' desire to provide risky loans, suggesting that it can be a proper instrument for the indicators of corruption (Chen et al., 2015). Moreover, lag values of bank risk, dependent variable, are used as additional instruments to address reverse causality. Technically, the inclusion of lagged dependent variables on the right-hand side of the empirical models allows to control for unobserved historical factors which have potential influences on current firm performance and risk taking, thus reducing omitted variable bias (Semykina et al., 2010).

As a robustness check and to overcome the other sources of endogeneity, we follow Meslier et al. (2017) and Bitar et al. (2019) and use the instrumental variables approach (IV) by considering 2SLS and GMM estimators. To test for the over-identifying restrictions, we report the Hansen J-Statistics, whereas the Kleibergen-Paap Wald F-statistics is used for the validity of our instrument. The significant Kleibergen-Paap F-Statistics indicates that the instruments we use are valid. While the insignificant value of the Hansen J-Statistics (over-identification test) shows that our instrument is not correlated with the error term.

The results of first and second stage regressions are presented in Table 8. The results of first stage regressions reveal that regulatory quality is negatively associated with corruption 
indicators, suggesting that lower ability of government to develop and implement the policies is related with a more corrupt economy. The findings of second stage regressions, for example taking conventional banks in consideration, clearly show that the instrumented corruption indicators are still negatively related with Z-score (banks' stability decreases as the severity of corruption increases, as a result banks are more vulnerable in corrupt economies). Using IV approach we find consistent evidence that corruption significantly affects bank risk-taking.

\section{[Insert Table 8 about here]}

\section{Concluding Remarks}

A variety of factors leading banks to take excessive risks and making them vulnerable have been documented in the literature, but research on the comparative impact of corruption on the risktaking of conventional vis-à-vis Islamic banks is still very limited. The most popular justifications of the beneficial or detrimental effects of corruption rest on the grease the wheels and sand the wheel hypotheses. On the detrimental side, corruption may hinder the increase of lending and raise the probability of borrowers' default by increasing the cost of loans. On the beneficial side, in corrupt economies, firms with higher productivity and efficiency can bid higher bribes and are more likely to receive more loans.

Combining prior research on bank risk and the impact of corruption, we study a unique sample of 840 observations on 70 Islamic banks and 70 conventional banks operating in 10 OIC countries over the 2012-2017 period. We find consistent evidence that higher levels of corruption are associated with higher risk-taking for both Islamic and conventional banks, in favor of the sand the wheel hypothesis in the corruption-development nexus. However, we find that, for Islamic banks, the impact of corruption on risk-taking is significantly reduced with higher representation of females in Shari'ah supervisory boards and higher academic qualifications of board members. Such findings are specific to Islamic banks and do not hold as strongly for conventional banks.

Our findings have important policy implications for developing and emerging economies that are evolving upward on the development ladder but are faced with increasing suspicion on whether their convergence is slowing down (Aiyar et al., 2013). On the one hand, the results of our paper regarding the detrimental impact of corruption on bank risk justify the urgency of the 
anti-corruption campaigns in these countries, particularly for conventional banks. On the other hand, our findings provide support for the positive contribution of Shari'ah supervision boards with the presence of female members and academically qualified members on boards to overcome the adverse effect of corruption on the riskiness of Islamic banks, and thereby underscore the need for enforcement and regulatory mechanisms for them to be more effective. 
mean equality test describes the mean difference in the performance between Islamic and conventional banks. ***, **, and * indicate significance at $1 \%, 5 \%$, and $10 \%$, respectively.

$Z$-score is the inverse of the probability of bank insolvency. $L L R$ is the ratio of loan loss reserves to gross loans. NPL is ratio of non-performing loans to gross loans. $L L P$ is the ratio of loan-loss provisions to average gross loans. $C I$ is the corruption indicator and key independent variable based on Transparency International's Corruption Perception Index but adjusted by equation (2). Governance variables include; board size that is the number of directors on board, CEO duality is a dummy variable that takes value one if the CEO is also the chairman of the board, and zero otherwise, female ratio is the number of female directors divided by total number of directors, and dummy variables take the value one if the auditing committee is independent and there is a separate risk management committee in the board structure, respectively. SSB attributes include; SSBACQ is the academic qualification of SSBs members refers to the number of SSBs members with M.Phil/doctorate degrees as a percentage of the total SSB members, SSBFR is the representation of females in SSBs implies a share of female members in SSBs, and SSBSZ is the number of members serving on the SSB of an Islamic bank at the end of each year. Bank-level variables include; capital asset ratio is the equity capital to asset ratio, bank size is the natural logarithm of the total assets, assets growth is the percentage growth in total assets in each year, cost inefficiency is the cost to income ratio, non-interest income is the share of non-interest income in total operating income. Country level controls include; GDP growth, natural resources, i.e. oil and mineral rents, and a set of institutional variables. The set of institutional variables include; entry barrier measures the stringency of entry requirements into the banking industry, the supervisory power is an index measuring supervisory agencies' power and authority to take specific preventive and corrective actions, and the deposit insurance variable indicates whether a country has explicit deposit insurance and whether depositors were fully compensated the last time a bank failed.

\begin{tabular}{|c|c|c|c|c|c|c|c|c|c|c|}
\hline \multicolumn{11}{|c|}{ Panel A: Descriptive statistics for the sample of Islamic and conventional banks } \\
\hline & \multicolumn{4}{|c|}{ Islamic Banks } & \multicolumn{6}{|c|}{ Conventional Banks } \\
\hline Variable & Mean & SD & Min & Max & & Mean & SD & Min & Max & T-test \\
\hline Z_Score & 2.070 & 1.160 & -1.250 & 5.470 & & 1.580 & 1.170 & -1.600 & 5.690 & $2.513 * * *$ \\
\hline $\operatorname{LLR}(\%)$ & 5.450 & 6.300 & 0.000 & 45.440 & & 6.210 & 8.360 & 0.000 & 49.570 & $-2.371 * * *$ \\
\hline NPL (\%) & 4.330 & 3.790 & 0.000 & 26.830 & & 4.910 & 5.200 & 0.000 & 32.310 & $-2.380 * *$ \\
\hline $\operatorname{LLP}(\%)$ & 8.730 & 9.090 & 0.000 & 57.750 & & 9.760 & 11.810 & 0.000 & 55.250 & $-3.305 * * *$ \\
\hline Board Size & 9.920 & 2.230 & 5.000 & 16.000 & & 10.100 & 3.300 & 4.000 & 21.000 & 0.855 \\
\hline CEO duality & 0.125 & 0.324 & 0.000 & 1.000 & & 0.1530 & 0.355 & 0.000 & 1.000 & -0.572 \\
\hline Female ratio & 0.038 & 0.0713 & 0.000 & 0.330 & & 0.055 & 0.096 & 0.000 & 0.500 & $-2.879 * *$ \\
\hline Audit Committee & 0.650 & 0.480 & 0.000 & 1.000 & & 0.550 & 0.500 & 0.000 & 1.000 & $-2.830 * *$ \\
\hline Risk Management & 0.710 & 0.450 & 0.000 & 1.000 & & 0.660 & 0.470 & 0.000 & 1.000 & $1.866^{*}$ \\
\hline SSBSZ & 4.700 & 2.590 & 2.000 & 12.000 & & & & & & \\
\hline SSBACQ & 0.540 & 0.390 & 0.000 & 1.000 & & & & & & \\
\hline SSBFR & 0.090 & 0.130 & 0.000 & 0.670 & & & & & & \\
\hline Assets Growth (\%) & 2.650 & 4.710 & -6.870 & 23.240 & & 2.820 & 4.740 & -9.020 & 24.520 & $3.624 * * *$ \\
\hline Bank Size & 9.000 & 1.350 & 7.000 & 14.560 & & 14.010 & 2.090 & 9.690 & 19.890 & $-3.899 * * *$ \\
\hline Capital Asset Ratio (\%) & 21.290 & 16.760 & 9.430 & 86.010 & & 14.510 & 7.600 & 5.010 & 39.160 & $2.373 * *$ \\
\hline Cost Inefficiency (\%) & 52.570 & 35.950 & 3.010 & 253.900 & & 47.580 & 39.705 & 1.000 & 272.900 & $-1.921 *$ \\
\hline Non-interest Income (\%) & 31.090 & 18.770 & 9.000 & 154.320 & & 25.890 & 14.110 & 0.490 & 141.500 & $-4.172 * * *$ \\
\hline \multicolumn{11}{|c|}{ Panel B: Descriptive statistics by country } \\
\hline & BHR & BGD & KWT & LBN & MYS & PAK & SAU & TUR & ARE & YEM \\
\hline Z_Score & 1.635 & 2.660 & 1.071 & 1.395 & 3.681 & 2.148 & 2.336 & 3.137 & 2.390 & 1.184 \\
\hline LLRs $(\%)$ & 6.366 & 9.951 & 5.274 & 7.363 & 1.441 & 5.775 & 5.877 & 9.599 & 6.465 & 5.515 \\
\hline NPLs $(\%)$ & 4.754 & 5.118 & 3.598 & 9.921 & 2.412 & 6.091 & 1.376 & 3.089 & 5.763 & 4.900 \\
\hline LLPs $(\%)$ & 5.341 & 6.495 & 14.463 & 8.719 & 10.631 & 8.107 & 15.071 & 9.137 & 7.465 & 6.784 \\
\hline $\mathrm{CI}$ & 54.00 & 74.00 & 57.00 & 72.00 & 51.00 & 70.00 & 52.00 & 56.00 & 31.00 & 82.00 \\
\hline Board Size & 12.521 & 13.677 & 9.833 & 9.292 & 10.018 & 8.383 & 10.104 & 9.958 & 9.324 & 8.389 \\
\hline CEO duality & 0.094 & 0.131 & 0.075 & 0.128 & 0.146 & 0.106 & 0.096 & 0.091 & 0.119 & 0.079 \\
\hline Female ratio & 0.013 & 0.086 & 0.009 & 0.045 & 0.062 & 0.038 & 0.000 & 0.057 & 0.016 & 0.010 \\
\hline Audit Committee & 0.643 & 0.615 & 0.333 & 0.417 & 0.536 & 0.633 & 0.708 & 0.903 & 0.528 & 0.361 \\
\hline Risk Management & 0.594 & 0.865 & 0.306 & 0.625 & 0.560 & 0.733 & 0.917 & 0.958 & 0.593 & 0.500 \\
\hline SSBSZ & 5.210 & 3.906 & 1.833 & 2.542 & 6.155 & 2.917 & 2.208 & 2.292 & 2.046 & 2.139 \\
\hline SSBACQ & 0.172 & 0.270 & 0.181 & 0.197 & 0.510 & 0.580 & 0.112 & 0.392 & 0.171 & 0.167 \\
\hline SSBFR & 0.020 & 0.070 & 0.020 & 0.030 & 0.100 & 0.060 & 0.000 & 0.050 & 0.000 & 0.000 \\
\hline Assets Growth (\%) & 5.210 & 4.886 & 7.404 & 4.811 & 7.746 & 2.189 & 2.642 & 8.855 & 5.763 & -3.752 \\
\hline Bank Size & 15.501 & 12.445 & 15.862 & 13.978 & 16.175 & 14.249 & 16.032 & 15.163 & 15.505 & 12.190 \\
\hline Capital Asset Ratio (\%) & 13.451 & 13.587 & 11.964 & 12.226 & 13.196 & 16.110 & 14.920 & 18.077 & 17.215 & 19.893 \\
\hline Cost Inefficiency (\%) & 52.240 & 66.563 & 60.063 & 47.635 & 44.582 & 57.549 & 39.334 & 50.877 & 41.628 & 54.961 \\
\hline Non-interest Income (\%) & 23.147 & 26.669 & 19.794 & 32.734 & 31.213 & 25.310 & 32.964 & 28.949 & 29.682 & 26.650 \\
\hline GDP growth & 4.276 & 6.591 & 4.592 & 4.822 & 5.231 & 4.756 & 5.781 & 5.860 & 4.797 & 2.069 \\
\hline Oil rent & 3.442 & 0.075 & 46.355 & 0.000 & 3.513 & 0.645 & 32.874 & 0.075 & 19.068 & 7.329 \\
\hline Mineral rent & 0.000 & 0.000 & 0.000 & 0.000 & 0.228 & 0.042 & 0.720 & 0.235 & 0.000 & 0.000 \\
\hline
\end{tabular}




\begin{tabular}{lcccccccccc} 
Entry Barrier & 8.000 & 8.000 & 8.000 & 8.000 & 8.000 & 8.000 & 8.000 & 8.000 & 0.000 & 0.000 \\
Supervisory Power & 12.000 & 5.000 & 13.000 & 11.000 & 12.000 & 12.000 & 13.000 & 13.000 & 0.000 & 0.000 \\
Deposit Insurance & 1.000 & 1.00 & 1.000 & 2.000 & 1.000 & 0.000 & 1.000 & 2.000 & 0.000 & 0.000 \\
\hline
\end{tabular}


Table 2: The effect of corruption on bank risk-taking: Baseline results

This table reports the benchmark results for Z-score and its components. We use Z-score as measure of insolvency risk. We break Z-score into two risk components; Leverage risk calculated as capital assets ratio divided by standard deviation of return on assets, and Portfolio risk computed as return on assets divided by standard deviation of return on assets. $C I$ is the corruption indicator based on Transparency International's Corruption Perception Index but adjusted by equation (2). Islamic Dummy and the interaction term of Islamic dummy with corruption indicator tests whether the risk-taking of Islamic banks could be differently affected by corruption compared to conventional banks. For baseline results we include SSBSZ as measure of Shari'ah supervision. SSBSZ is the number of members serving on the SSB of an Islamic bank at the end of each year. SSBSZ $\times C I$ is the interaction term between corruption and Shari'ah supervision. Bank-level control variables include; capital asset ratio is the equity capital to asset ratio, bank size is the natural logarithm of the total assets, assets growth is the percentage growth in total assets in each year, cost inefficiency is the cost to income ratio, non-interest income is the share of non-interest income in total operating income. Country level controls include; GDP growth, natural resources, i.e. oil and mineral rents, and a set of institutional variables. The set of institutional variables include; entry barrier measures the stringency of entry requirements into the banking industry, the supervisory power is an index measuring supervisory agencies' power and authority to take specific preventive and corrective actions, and the deposit insurance variable indicates whether a country has explicit deposit insurance and whether depositors were fully compensated the last time a bank failed. We apply random effect technique with robust standard errors for our estimations. Robust standard-errors are reported in parentheses. $* * *, * *$, and $*$ indicate significance at $1 \%, 5 \%$, and $10 \%$, respectively.

\begin{tabular}{|c|c|c|c|c|c|c|c|c|c|c|c|c|c|c|c|c|c|c|}
\hline \multirow[b]{3}{*}{ VARIABLES } & \multicolumn{6}{|c|}{ Z-score models } & \multicolumn{6}{|c|}{ Leverage risk models } & \multicolumn{6}{|c|}{ Portfolio risk models } \\
\hline & \multicolumn{2}{|c|}{ Full Sample } & \multicolumn{2}{|c|}{ Sample of IBs } & \multicolumn{2}{|c|}{ Sample of CBs } & \multicolumn{2}{|c|}{ Full Sample } & \multicolumn{2}{|c|}{ Sample of IBs } & \multicolumn{2}{|c|}{ Sample of CBs } & \multicolumn{2}{|c|}{ Full Sample } & \multicolumn{2}{|c|}{ Sample of IBs } & \multicolumn{2}{|c|}{ Sample of CBs } \\
\hline & (1) & (2) & (3) & (4) & (5) & (6) & (7) & (8) & (9) & (10) & (11) & (12) & (13) & (14) & (15) & (16) & (17) & (18) \\
\hline $\mathrm{CI}\left(\beta_{1}\right)$ & $\begin{array}{c}-0.520^{* *} \\
(0.241)\end{array}$ & $\begin{array}{c}-0.511 * * \\
(0.242)\end{array}$ & $\begin{array}{c}-0.083^{*} \\
(0.047)\end{array}$ & $\begin{array}{c}-0.072^{* *} \\
(0.035)\end{array}$ & $\begin{array}{c}-0.478 * \\
(0.245)\end{array}$ & $\begin{array}{c}-0.472^{*} \\
(0.246)\end{array}$ & $\begin{array}{c}-1.74 * * * \\
(0.113)\end{array}$ & $\begin{array}{c}-0.851 * * * \\
(0.115)\end{array}$ & $\begin{array}{c}-1.59^{* * *} \\
(0.144)\end{array}$ & $\begin{array}{c}-0.586^{* * * *} \\
(0.125)\end{array}$ & $\begin{array}{c}-1.724 * * * \\
(0.113)\end{array}$ & $\begin{array}{c}-0.837 * * * \\
(0.115)\end{array}$ & $\begin{array}{c}-3.49 * * * \\
(0.283)\end{array}$ & $\begin{array}{c}-2.48^{* * * *} \\
(0.309)\end{array}$ & $\begin{array}{c}-3.47 * * * \\
(0.286)\end{array}$ & $\begin{array}{c}-2.45^{* * * *} \\
(0.311)\end{array}$ & $\begin{array}{c}-3.94 * * * \\
(0.368)\end{array}$ & $\begin{array}{c}-2.98 * * * \\
(0.411)\end{array}$ \\
\hline IB Dummy & $\begin{array}{c}0.427 * * * \\
(0.137)\end{array}$ & $\begin{array}{c}0.429^{* * * *} \\
(0.138)\end{array}$ & & & & & $\begin{array}{c}0.164 * * \\
(0.064)\end{array}$ & $\begin{array}{c}0.165 * * \\
(0.064)\end{array}$ & & & & & $\begin{array}{c}0.163 * * \\
(0.069)\end{array}$ & $\begin{array}{c}0.164 * * \\
(0.069)\end{array}$ & & & & \\
\hline IB_Dummy $\times$ CI $\left(\beta_{3}\right)$ & $\begin{array}{c}0.124 * * \\
(0.052)\end{array}$ & $\begin{array}{c}0.123 * * \\
(0.058)\end{array}$ & & & & & $\begin{array}{c}0.423 * * \\
(0.205)\end{array}$ & $\begin{array}{c}0.321 \\
(0.541)\end{array}$ & & & & & $\begin{array}{l}0.451^{*} \\
(0.250)\end{array}$ & $\begin{array}{l}0.439^{*} \\
(0.242)\end{array}$ & & & & \\
\hline SSBSZ & $\begin{array}{c}0.018 * * \\
(0.009)\end{array}$ & $\begin{array}{c}0.019 * * \\
(0.009)\end{array}$ & $\begin{array}{c}0.095^{* *} \\
(0.041)\end{array}$ & $\begin{array}{l}0.096^{*} \\
(0.051)\end{array}$ & & & $\begin{array}{c}0.043 * * \\
(0.020)\end{array}$ & $\begin{array}{c}0.044 * * \\
(0.020)\end{array}$ & $\begin{array}{l}0.022^{*} \\
(0.012)\end{array}$ & $\begin{array}{c}0.025 * * \\
(0.012)\end{array}$ & & & $\begin{array}{c}0.003 * * * \\
(0.001)\end{array}$ & $\begin{array}{c}0.003 * * * \\
(0.001)\end{array}$ & $\begin{array}{c}0.006^{* *} \\
(0.003)\end{array}$ & $\begin{array}{c}0.006^{* *} \\
(0.003)\end{array}$ & & \\
\hline $\operatorname{SSBSZ} \times C I\left(\beta_{5}\right)$ & $\begin{array}{l}0.055^{*} \\
(0.03)\end{array}$ & $\begin{array}{c}0.050 * * \\
(0.02)\end{array}$ & $\begin{array}{l}0.014 * \\
(0.008)\end{array}$ & $\begin{array}{c}0.017^{* *} \\
(0.007)\end{array}$ & & & $\begin{array}{c}0.630 * * * \\
(0.010)\end{array}$ & $\begin{array}{c}0.710 * * * \\
(0.020)\end{array}$ & $\begin{array}{l}0.212^{*} \\
(0.120)\end{array}$ & $\begin{array}{l}0.213^{*} \\
(0.119)\end{array}$ & & & $\begin{array}{c}0.024 \\
(0.031)\end{array}$ & $\begin{array}{c}0.031 \\
(0.020)\end{array}$ & $\begin{array}{c}0.090 \\
(0.076)\end{array}$ & $\begin{array}{c}0.012 \\
(0.030)\end{array}$ & & \\
\hline Bank Size & $\begin{array}{l}0.289 * \\
(0.162)\end{array}$ & $\begin{array}{l}0.275^{*} \\
(0.160)\end{array}$ & $\begin{array}{c}0.021 \\
(0.140)\end{array}$ & $\begin{array}{c}0.012 \\
(0.138)\end{array}$ & $\begin{array}{c}0.626 * * \\
(0.279)\end{array}$ & $\begin{array}{c}0.621 * * \\
(0.278)\end{array}$ & $\begin{array}{c}0.046 \\
(0.059)\end{array}$ & $\begin{array}{c}0.044 \\
(0.060)\end{array}$ & $\begin{array}{c}0.064 \\
(0.060)\end{array}$ & $\begin{array}{c}0.070 \\
(0.061)\end{array}$ & $\begin{array}{c}0.067 \\
(0.059)\end{array}$ & $\begin{array}{c}0.072 \\
(0.061)\end{array}$ & $\begin{array}{c}0.285 \\
(0.511)\end{array}$ & $\begin{array}{c}0.338 \\
(0.510)\end{array}$ & $\begin{array}{l}0.134 * \\
(0.074)\end{array}$ & $\begin{array}{l}0.130^{*} \\
(0.075)\end{array}$ & $\begin{array}{l}0.134^{*} \\
(0.075)\end{array}$ & $\begin{array}{l}0.130^{*} \\
(0.075)\end{array}$ \\
\hline Capital Ratio & $\begin{array}{l}1.036 \\
(3.083)\end{array}$ & $\begin{array}{l}1.031 \\
(3.083)\end{array}$ & $\begin{array}{c}1.573 * * * \\
(0.106)\end{array}$ & $\begin{array}{c}1.689 * * * \\
(0.107)\end{array}$ & $\begin{array}{c}1.017 \\
(1.120)\end{array}$ & $\begin{array}{l}1.017 \\
(1.120)\end{array}$ & $\begin{array}{l}1.175 \\
(2.412)\end{array}$ & $\begin{array}{l}1.186 \\
(2.413)\end{array}$ & $\begin{array}{l}2.426^{*} \\
(1.335)\end{array}$ & $\begin{array}{l}2.444 * \\
(1.341)\end{array}$ & $\begin{array}{l}1.439 \\
(3.522)\end{array}$ & $\begin{array}{c}1.454 \\
(3.525)\end{array}$ & $\begin{array}{c}0.981 \\
(1.003)\end{array}$ & $\begin{array}{c}0.987 \\
(1.003)\end{array}$ & $\begin{array}{l}1.745^{*} \\
(1.048)\end{array}$ & $\begin{array}{l}1.749 * \\
(1.056)\end{array}$ & $\begin{array}{c}0.844 \\
(1.581)\end{array}$ & $\begin{array}{c}0.848 \\
(1.565)\end{array}$ \\
\hline Assets Growth & $\begin{array}{c}0.023^{* *} \\
(0.011)\end{array}$ & $\begin{array}{c}0.027 \\
(0.020)\end{array}$ & $\begin{array}{l}0.010 \\
(0.014)\end{array}$ & $\begin{array}{c}0.012 \\
(0.014)\end{array}$ & $\begin{array}{c}0.056 * * * \\
(0.016)\end{array}$ & $\begin{array}{c}0.053 * * * \\
(0.016)\end{array}$ & $\begin{array}{c}0.006 * * \\
(0.003)\end{array}$ & $\begin{array}{c}0.006^{* * *} \\
(0.003)\end{array}$ & $\begin{array}{c}0.008^{* *} \\
(0.004)\end{array}$ & $\begin{array}{l}0.008^{* * *} \\
(0.004)\end{array}$ & $\begin{array}{l}0.008^{*} \\
(0.005)\end{array}$ & $\begin{array}{c}0.009 * * \\
(0.004)\end{array}$ & $\begin{array}{c}0.006 \\
(0.004)\end{array}$ & $\begin{array}{c}0.006 \\
(0.004)\end{array}$ & $\begin{array}{c}0.004 \\
(0.007)\end{array}$ & $\begin{array}{c}0.004 \\
(0.007)\end{array}$ & $\begin{array}{c}0.0042 \\
(0.0073)\end{array}$ & $\begin{array}{c}0.0043 \\
(0.0075)\end{array}$ \\
\hline Inefficiency & $\begin{array}{c}-2.288^{*} \\
(1.194)\end{array}$ & $\begin{array}{c}-2.293 * * \\
(1.144)\end{array}$ & $\begin{array}{l}-0.283 \\
(0.338)\end{array}$ & $\begin{array}{l}-0.288 \\
(0.356)\end{array}$ & $\begin{array}{l}-0.028^{*} \\
(0.015)\end{array}$ & $\begin{array}{c}-0.027^{*} \\
(0.015)\end{array}$ & $\begin{array}{l}-0.052 \\
(1.152)\end{array}$ & $\begin{array}{l}-0.058 \\
(1.145)\end{array}$ & $\begin{array}{c}-0.123 \\
(1.017)\end{array}$ & $\begin{array}{l}-0.126 \\
(1.019)\end{array}$ & $\begin{array}{l}-0.098 \\
(2.021)\end{array}$ & $\begin{array}{l}-0.095 \\
(2.025)\end{array}$ & $\begin{array}{c}-0.840^{* *} \\
(0.396)\end{array}$ & $\begin{array}{c}-0.652^{* *} \\
(0.276)\end{array}$ & $\begin{array}{c}-0.251^{*} \\
(0.137)\end{array}$ & $\begin{array}{c}-0.270^{* *} \\
(0.107)\end{array}$ & $\begin{array}{l}-0.189 \\
(0.163)\end{array}$ & $\begin{array}{l}-0.128 \\
(0.191)\end{array}$ \\
\hline NII & $\begin{array}{l}-0.422 \\
(0.922)\end{array}$ & $\begin{array}{l}-0.427 \\
(0.924)\end{array}$ & $\begin{array}{c}0.002 \\
(0.005)\end{array}$ & $\begin{array}{l}0.003 * * \\
(0.0015)\end{array}$ & $\begin{array}{l}-1.189 \\
(1.110)\end{array}$ & $\begin{array}{l}-1.164 \\
(1.111)\end{array}$ & $\begin{array}{l}-0.002 \\
(0.005)\end{array}$ & $\begin{array}{l}-0.002 \\
(0.002)\end{array}$ & $\begin{array}{c}0.005 \\
(0.004)\end{array}$ & $\begin{array}{c}0.004 \\
(0.003)\end{array}$ & $\begin{array}{l}-0.004 \\
(0.003)\end{array}$ & $\begin{array}{l}-0.004 \\
(0.003)\end{array}$ & $\begin{array}{l}-0.002 \\
(0.003)\end{array}$ & $\begin{array}{l}-0.002 \\
(0.003)\end{array}$ & $\begin{array}{c}0.005 \\
(0.004)\end{array}$ & $\begin{array}{c}0.005 \\
(0.004)\end{array}$ & $\begin{array}{l}-0.006 \\
(0.004)\end{array}$ & $\begin{array}{l}-0.006 \\
(0.004)\end{array}$ \\
\hline GDP Growth & & $\begin{array}{c}0.007 * * * \\
(0.002)\end{array}$ & & $\begin{array}{c}0.024 * * * \\
(0.003)\end{array}$ & & $\begin{array}{c}0.019 * * * \\
(0.002)\end{array}$ & & $\begin{array}{c}0.009 * * \\
(0.004)\end{array}$ & & $\begin{array}{c}0.007 * * \\
(0.003)\end{array}$ & & $\begin{array}{l}0.007 * \\
(0.004)\end{array}$ & & $\begin{array}{c}0.001^{*} \\
(0.0006)\end{array}$ & & $\begin{array}{c}0.009 * * * \\
(0.002)\end{array}$ & & $\begin{array}{c}0.009^{* * *} \\
(0.002)\end{array}$ \\
\hline Oil Rent & & $\begin{array}{l}-0.005 \\
(0.007)\end{array}$ & & $\begin{array}{l}-0.005 \\
(0.006)\end{array}$ & & $\begin{array}{l}-0.001 \\
(0.009)\end{array}$ & & $\begin{array}{l}-0.004 \\
(0.004)\end{array}$ & & $\begin{array}{l}-0.006 \\
(0.007)\end{array}$ & & $\begin{array}{l}-0.006 \\
(0.007)\end{array}$ & & $\begin{array}{l}-0.004 \\
(0.003)\end{array}$ & & $\begin{array}{c}-0.007^{*} \\
(0.004)\end{array}$ & & $\begin{array}{l}-0.007^{*} \\
(0.004)\end{array}$ \\
\hline
\end{tabular}




\begin{tabular}{|c|c|c|c|c|c|c|c|c|c|c|c|c|c|c|c|c|c|c|}
\hline \multicolumn{2}{|l|}{ Mineral Rent } & $\begin{array}{l}0.060^{*} \\
(0.034)\end{array}$ & & $\begin{array}{c}0.134 \\
(0.095)\end{array}$ & & $\begin{array}{c}0.084 \\
(0.084)\end{array}$ & & $\begin{array}{l}0.014^{*} \\
(0.008)\end{array}$ & & $\begin{array}{c}0.017 \\
(0.034)\end{array}$ & & $\begin{array}{c}0.014^{* * *} \\
(0.006)\end{array}$ & & $\begin{array}{l}0.023^{*} \\
(0.013)\end{array}$ & & $\begin{array}{c}0.014 \\
(0.024)\end{array}$ & & $\begin{array}{c}0.013 \\
(0.024)\end{array}$ \\
\hline \multicolumn{2}{|l|}{ Entry Barrier } & $\begin{array}{l}1.015 * * \\
(0.427)\end{array}$ & & $\begin{array}{c}0.545 \\
(0.507)\end{array}$ & & $\begin{array}{l}1.381^{*} \\
(0.807)\end{array}$ & & $\begin{array}{c}0.063 \\
(0.162)\end{array}$ & & $\begin{array}{l}0.220 * \\
(0.132)\end{array}$ & & $\begin{array}{l}0.223^{*} \\
(0.131)\end{array}$ & & $\begin{array}{c}0.906^{* * * *} \\
(0.168)\end{array}$ & & $\begin{array}{c}1.067 * * * \\
(0.298)\end{array}$ & & $\begin{array}{c}1.071 * * * \\
(0.298)\end{array}$ \\
\hline \multicolumn{2}{|l|}{ Supervisory Power } & $\begin{array}{c}0.647 * * \\
(0.282)\end{array}$ & & $\begin{array}{c}0.354 \\
(0.332)\end{array}$ & & $\begin{array}{l}0.875^{*} \\
(0.469)\end{array}$ & & $\begin{array}{c}0.089 * * * \\
(0.006)\end{array}$ & & $\begin{array}{c}0.018^{* * * *} \\
(0.004)\end{array}$ & & $\begin{array}{c}0.019^{* * * *} \\
(0.004)\end{array}$ & & $\begin{array}{c}0.551 * * * \\
(0.111)\end{array}$ & & $\begin{array}{c}0.657 * * * \\
(0.198)\end{array}$ & & $\begin{array}{c}0.660 * * * \\
(0.198)\end{array}$ \\
\hline \multicolumn{2}{|l|}{ Deposit Insurance } & $\begin{array}{c}-0.55^{* * *} * \\
(0.175)\end{array}$ & & $\begin{array}{l}-0.357 \\
(0.239)\end{array}$ & & $\begin{array}{c}-0.71 * * * \\
(0.253)\end{array}$ & & $\begin{array}{c}-0.340^{* * *} \\
(0.059)\end{array}$ & & $\begin{array}{c}-0.216^{* * *} \\
(0.033)\end{array}$ & & $\begin{array}{c}-0.216^{* * *} * \\
(0.033)\end{array}$ & & $\begin{array}{c}-0.178^{* * *} \\
(0.062)\end{array}$ & & $\begin{array}{c}-0.238^{* *} \\
(0.108)\end{array}$ & & $\begin{array}{c}-0.240 * * \\
(0.108)\end{array}$ \\
\hline Constant & $\begin{array}{c}8.160^{* * * *} \\
(0.161)\end{array}$ & $\begin{array}{c}9.020^{* * * *} \\
(0.166)\end{array}$ & $\begin{array}{c}7.915^{* * * *} \\
(0.263)\end{array}$ & $\begin{array}{c}8.455^{* * * *} \\
(0.216)\end{array}$ & $\begin{array}{c}8.018^{* * * *} \\
(0.171)\end{array}$ & $\begin{array}{c}9.126 * * * \\
(0.177)\end{array}$ & $\begin{array}{c}3.221^{* * * *} \\
(0.066)\end{array}$ & $\begin{array}{c}4.222 * * * * \\
(0.067)\end{array}$ & $\begin{array}{c}2.947 * * * \\
(0.062)\end{array}$ & $\begin{array}{c}4.058^{* * * *} \\
(0.095)\end{array}$ & $\begin{array}{c}2.960 * * * \\
(0.057)\end{array}$ & $\begin{array}{c}4.074 * * * \\
(0.093)\end{array}$ & $\begin{array}{c}2.810^{* * * *} \\
(0.062)\end{array}$ & $\begin{array}{c}3.270 * * * \\
(0.068)\end{array}$ & $\begin{array}{c}2.773 * * * \\
(0.068)\end{array}$ & $\begin{array}{c}3.260 * * * \\
(0.079)\end{array}$ & $\begin{array}{c}2.762 * * * * \\
(0.070)\end{array}$ & $\begin{array}{c}3.245^{* * * *} \\
(0.082)\end{array}$ \\
\hline Year_Dummies & Yes & Yes & Yes & Yes & Yes & Yes & Yes & Yes & Yes & Yes & Yes & Yes & Yes & Yes & Yes & Yes & Yes & Yes \\
\hline Country_Dummies & Yes & Yes & Yes & Yes & Yes & Yes & Yes & Yes & Yes & Yes & Yes & Yes & Yes & Yes & Yes & Yes & Yes & Yes \\
\hline Bank controls & Yes & Yes & Yes & Yes & Yes & Yes & Yes & Yes & Yes & Yes & Yes & Yes & Yes & Yes & Yes & Yes & Yes & Yes \\
\hline Country controls & No & Yes & No & Yes & No & Yes & No & Yes & No & Yes & No & Yes & No & Yes & No & Yes & No & Yes \\
\hline Observations & 840 & 840 & 420 & 420 & 420 & 420 & 840 & 840 & 420 & 420 & 420 & 420 & 840 & 840 & 420 & 420 & 420 & 420 \\
\hline No. of Bank & 140 & 140 & 70 & 70 & 70 & 70 & 140 & 140 & 70 & 70 & 70 & 70 & 140 & 140 & 70 & 70 & 70 & 70 \\
\hline R-Square & 0.394 & 0.468 & 0.341 & 0.349 & 0.303 & 0.309 & 0.415 & 0.508 & 0.286 & 0.289 & 0.362 & 0.368 & 0.229 & 0.304 & 0.342 & 0.348 & 0.265 & 0.272 \\
\hline \multicolumn{19}{|c|}{ Panel B: The impact of corruption on risk taking of Islamic bank $\left(\beta_{1}+\beta_{3}\right)$} \\
\hline$H_{0}: \beta_{1}=\left(\beta_{1}+\beta_{3}\right)$ & $\begin{array}{c}-0.396^{* * *} \\
(0.171)\end{array}$ & $\begin{array}{c}-0.388^{* *} \\
(0.162)\end{array}$ & & & & & $\begin{array}{c}-1.317 * * * * \\
(0.113)\end{array}$ & $\begin{array}{c}-0.530 * * * \\
(0.115)\end{array}$ & & & & & $\begin{array}{c}-3.039 * * \\
(1.283)\end{array}$ & $\begin{array}{c}-2.041^{* * * *} \\
(0.309)\end{array}$ & & & & \\
\hline \multicolumn{19}{|c|}{ Panel C: The impact of corruption on risk taking of Islamic bank: the role of SSBs size $\left(\beta_{1}+\beta_{5}\right)$} \\
\hline$H_{0}: \beta_{1}=\left(\beta_{1}+\beta_{5}\right)$ & $\begin{array}{c}-0.465 * * \\
(0.2109)\end{array}$ & $\begin{array}{c}-0.461 * * \\
(0.212)\end{array}$ & $\begin{array}{c}-0.069^{* * *} \\
(0.034)\end{array}$ & $\begin{array}{l}-0.055 \\
(0.105)\end{array}$ & & & $\begin{array}{c}-1.110^{* * *} \\
(0.513)\end{array}$ & $\begin{array}{c}-0.141^{* * *} \\
(0.014)\end{array}$ & $\begin{array}{c}-1.378 * * \\
(0.644)\end{array}$ & $\begin{array}{c}-0.373^{* * *} \\
(0.115)\end{array}$ & & & $\begin{array}{l}-3.466 \\
(4.013)\end{array}$ & $\begin{array}{l}-2.449 \\
(3.309)\end{array}$ & $\begin{array}{l}-3.380^{*} \\
(1.901)\end{array}$ & $\begin{array}{l}-2.438 \\
(2.411)\end{array}$ & & \\
\hline
\end{tabular}


Table 3: The effect of corruption on bank risk-taking: the role of the attributes of Shari'ah supervision

This table reports the results for the role of the Shari'ah supervisory board structure. We use Z-score as measure of insolvency risk. Z-score is the inverse of the probability of bank insolvency. We break Z-score into two risk components; Leverage risk calculated as capital assets ratio divided by standard deviation of return on assets, and Portfolio risk computed as return on assets divided by standard deviation of return on assets. $C I$ is the corruption indicator based on Transparency International's Corruption Perception Index but adjusted by equation (2). SSB attributes include; SSBACQ is the academic qualification of SSBs members refers to the number of SSBs members with M.Phil/doctorate degrees as a percentage of the total SSB members, SSBFR is the representation of females in SSBs implies a share of female members in SSBs, and SSBSZ is the number of members serving on the SSB of an Islamic bank at the end of each year. In all regressions, we use a full set of independent and control variables that include corruption indicator, bank characteristics and macroeconomic variables. We only report the coefficients of corruption indicator and its interaction with SSBs attributes for brevity. We apply random effect technique with robust standard errors for our estimations. Robust standard-errors are reported in parentheses. $* * *, * *$, and $*$ indicate significance at $1 \%, 5 \%$, and $10 \%$, respectively.

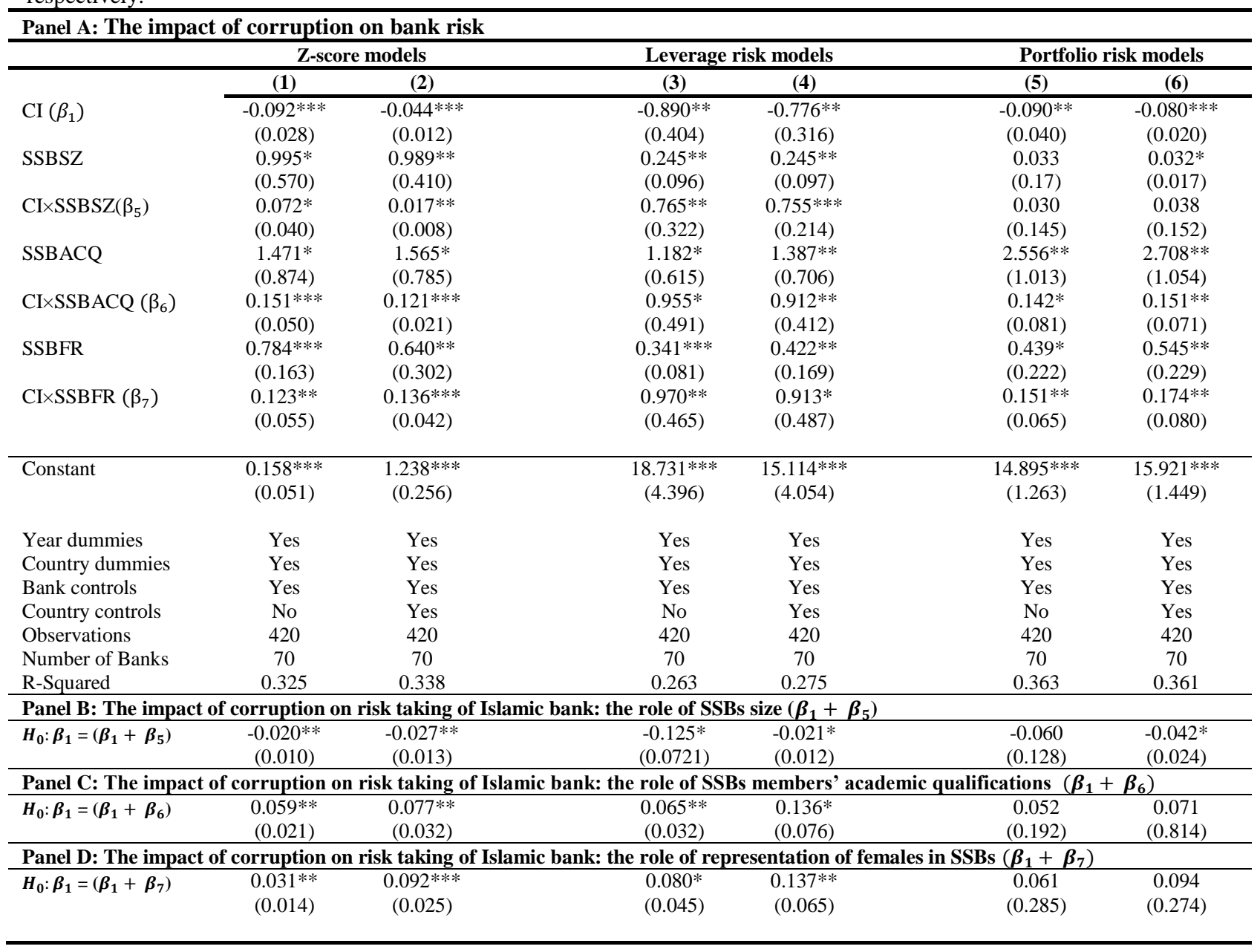


Table 4: The effect of corruption on bank risk-taking: the role of conventional governance

This table reports the results for the role of the conventional governance structure. We use Z-score as measure of insolvency risk. $Z$-score is the inverse of the probability of bank insolvency. We break Z-score into two risk components; Leverage risk calculated as capital assets ratio divided by standard deviation of return on assets, and Portfolio risk computed as return on assets divided by standard deviation of return on assets. $C I$ is the corruption indicator based on Transparency International's Corruption Perception Index but adjusted by equation (2). Governance variables include; board size that is the number of directors on board, $C B A C Q$ is the academic qualification of board members of conventional banks refers to the number of board members with M.Phil/doctorate degrees, as a percentage of the total board members, $C B F R$ is the female ratio computed as the number of female directors divided by total number of directors, CEO duality is a dummy variable that takes value one if the CEO is also the chairman of the board, and zero otherwise, female ratio is the number of female directors divided by total number of directors, and dummy variables take the value one if the auditing committee is independent and there is a separate risk management committee in the board structure, respectively. In all regressions, we use a full set of independent and control variables that include corruption indicator, bank characteristics and macroeconomic variables. We only report the coefficients of corruption indicator and its interaction with governance variables for brevity. We apply random effect technique with robust standard errors for our estimations. Robust standard-errors are reported in parentheses. ***, **, and * indicate significance at $1 \%$, $5 \%$, and $10 \%$, respectively.

\begin{tabular}{|c|c|c|c|c|c|c|}
\hline & \multicolumn{2}{|c|}{ Z-score models } & \multicolumn{2}{|c|}{ Leverage risk models } & \multicolumn{2}{|c|}{ Portfolio risk models } \\
\hline & (1) & (2) & (3) & (4) & (5) & (6) \\
\hline $\mathrm{CI}\left(\beta_{1}\right)$ & $\begin{array}{c}-1.030^{* * *} \\
(0.218)\end{array}$ & $\begin{array}{c}-1.510^{* * *} * \\
(0.335)\end{array}$ & $\begin{array}{c}-1.071^{* * *} * \\
(0.345)\end{array}$ & $\begin{array}{c}-1.016 * * \\
(0.440)\end{array}$ & $\begin{array}{c}-0.890 * * * \\
(0.070)\end{array}$ & $\begin{array}{c}-0.630 \text { *** } \\
(0.060)\end{array}$ \\
\hline Board size $\left(\beta_{2}\right)$ & $\begin{array}{c}1.030 \\
(2.060)\end{array}$ & $\begin{array}{c}1.070 \\
(1.090)\end{array}$ & $\begin{array}{c}0.210 \\
(0.350)\end{array}$ & $\begin{array}{c}0.330 \\
(0.530)\end{array}$ & $\begin{array}{c}1.078 \\
(1.115)\end{array}$ & $\begin{array}{c}1.023 \\
(1.116)\end{array}$ \\
\hline $\mathrm{CI} \times$ Board size $\left(\beta_{1} * \beta_{2}\right)$ & $\begin{array}{c}1.024 \\
(1.100)\end{array}$ & $\begin{array}{c}1.040 \\
(2.110)\end{array}$ & $\begin{array}{l}1.050 \\
(2.060)\end{array}$ & $\begin{array}{c}1.010 \\
(2.070)\end{array}$ & $\begin{array}{c}0.152 \\
(1.134)\end{array}$ & $\begin{array}{c}0.029 \\
(1.135)\end{array}$ \\
\hline $\operatorname{CBACQ}\left(\beta_{3}\right)$ & $\begin{array}{c}2.985 * * * \\
(0.887)\end{array}$ & $\begin{array}{c}2.981 * * * \\
(0.894)\end{array}$ & $\begin{array}{c}0.965 * * \\
(0.485)\end{array}$ & $\begin{array}{c}0.973 * * \\
(0.440)\end{array}$ & $\begin{array}{c}0.035 * * \\
(0.017)\end{array}$ & $\begin{array}{c}0.034 * * \\
(0.017)\end{array}$ \\
\hline $\operatorname{CI} \times \operatorname{CBACQ}\left(\beta_{1} * \beta_{3}\right)$ & $\begin{array}{c}0.986 \\
(2.543)\end{array}$ & $\begin{array}{l}0.033^{*} \\
(0.018)\end{array}$ & $\begin{array}{c}0.079 \\
(0.456)\end{array}$ & $\begin{array}{l}0.034 * \\
(0.020)\end{array}$ & $\begin{array}{c}0.625 \\
(1.146)\end{array}$ & $\begin{array}{l}0.522 * \\
(0.310)\end{array}$ \\
\hline $\operatorname{CBFR}\left(\beta_{4}\right)$ & $\begin{array}{l}1.603^{*} \\
(0.980)\end{array}$ & $\begin{array}{l}1.578 * * \\
(0.790)\end{array}$ & $\begin{array}{l}1.692 * * \\
(0.708)\end{array}$ & $\begin{array}{l}1.731 * * \\
(0.767)\end{array}$ & $\begin{array}{c}1.970 * * * \\
(0.563)\end{array}$ & $\begin{array}{c}2.000 * * * \\
(0.565)\end{array}$ \\
\hline $\operatorname{CI} \times \operatorname{CBFR}\left(\beta_{1} * \beta_{4}\right)$ & $\begin{array}{c}1.000 \\
(2.160)\end{array}$ & $\begin{array}{l}1.410^{*} \\
(0.830)\end{array}$ & $\begin{array}{c}0.263 \\
(1.513)\end{array}$ & $\begin{array}{l}0.382^{*} \\
(0.211) \\
\end{array}$ & $\begin{array}{c}0.541 \\
(2.335) \\
\end{array}$ & $\begin{array}{c}0.472 \\
(2.337) \\
\end{array}$ \\
\hline CEO Duality $\left(\beta_{5}\right)$ & $\begin{array}{l}-0.115^{*} \\
(0.067)\end{array}$ & $\begin{array}{c}-0.198 * * \\
(0.079)\end{array}$ & $\begin{array}{l}-0.210 \\
(0.212)\end{array}$ & $\begin{array}{l}-0.216 \\
(0.211)\end{array}$ & $\begin{array}{l}-0.092 \\
(0.290)\end{array}$ & $\begin{array}{l}-0.095 \\
(0.286)\end{array}$ \\
\hline CI $\times$ CEO Duality $\left(\beta_{1} * \beta_{5}\right)$ & $\begin{array}{c}-0.096 \\
(0.066)\end{array}$ & $\begin{array}{l}-0.071 \\
(0.075)\end{array}$ & $\begin{array}{c}-0.202 \\
(0.223)\end{array}$ & $\begin{array}{c}-0.211 \\
(0.221)\end{array}$ & $\begin{array}{l}-0.074 \\
(0.298)\end{array}$ & $\begin{array}{l}-0.088 \\
(0.292)\end{array}$ \\
\hline Audit Committee $\left(\beta_{6}\right)$ & $\begin{array}{c}0.241 \\
(0.342)\end{array}$ & $\begin{array}{c}0.245 \\
(0.342)\end{array}$ & $\begin{array}{c}0.762 \\
(0.844)\end{array}$ & $\begin{array}{c}0.783 \\
(0.836)\end{array}$ & $\begin{array}{c}0.226 \\
(0.398)\end{array}$ & $\begin{array}{c}0.255 \\
(0.417)\end{array}$ \\
\hline CI×Audit Committee $\left(\beta_{1} * \beta_{6}\right)$ & $\begin{array}{c}0.122 \\
(0.192)\end{array}$ & $\begin{array}{l}0.121 \\
(0.193)\end{array}$ & $\begin{array}{c}0.441 \\
(0.325)\end{array}$ & $\begin{array}{c}0.434 \\
(0.323)\end{array}$ & $\begin{array}{c}0.240 \\
(0.370)\end{array}$ & $\begin{array}{c}0.260 \\
(0.410)\end{array}$ \\
\hline Risk Management $\left(\beta_{7}\right)$ & $\begin{array}{c}0.980 * * \\
(0.430)\end{array}$ & $\begin{array}{c}0.940 * * \\
(0.390)\end{array}$ & $\begin{array}{c}1.190 * * * \\
(0.340)\end{array}$ & $\begin{array}{c}1.160 * * * \\
(0.370)\end{array}$ & $\begin{array}{l}1.000 * * \\
(0.400)\end{array}$ & $\begin{array}{l}1.010^{* *} \\
(0.400)\end{array}$ \\
\hline CI $\times$ Risk Management $\left(\beta_{1} * \beta_{7}\right)$ & $\begin{array}{c}0.950 \\
(0.826) \\
\end{array}$ & $\begin{array}{c}0.921 \\
(0.829) \\
\end{array}$ & $\begin{array}{c}1.570 \\
(1.780) \\
\end{array}$ & $\begin{array}{c}1.230 \\
(1.630) \\
\end{array}$ & $\begin{array}{c}1.320 \\
(2.070)\end{array}$ & $\begin{array}{c}1.300 \\
(2.090) \\
\end{array}$ \\
\hline Constant & $\begin{array}{c}30.120 \\
(26.250)\end{array}$ & $\begin{array}{c}75.485 \\
(44.238)\end{array}$ & $\begin{array}{c}1.911 \\
(2.622)\end{array}$ & $\begin{array}{l}9.900 * \\
(6.003)\end{array}$ & $\begin{array}{l}11.310^{*} \\
(6.784)\end{array}$ & $\begin{array}{c}12.514 * * \\
(6.232)\end{array}$ \\
\hline Year dummies & Yes & Yes & Yes & Yes & Yes & Yes \\
\hline Country dummies & Yes & Yes & Yes & Yes & Yes & Yes \\
\hline $\begin{array}{l}\text { Bank controls } \\
\text { Country controls }\end{array}$ & $\begin{array}{l}\text { Yes } \\
\text { No }\end{array}$ & $\begin{array}{l}\text { Yes } \\
\text { Yes }\end{array}$ & $\begin{array}{l}\text { Yes } \\
\text { No }\end{array}$ & $\begin{array}{l}\text { Yes } \\
\text { Yes }\end{array}$ & $\begin{array}{l}\text { Yes } \\
\text { No }\end{array}$ & $\begin{array}{l}\text { Yes } \\
\text { Yes }\end{array}$ \\
\hline Observations & 420 & 420 & 420 & 420 & 420 & 420 \\
\hline Number of Banks & 70 & 70 & 70 & 70 & 70 & 70 \\
\hline R-Squared & 0.281 & 0.307 & 0.304 & 0.319 & 0.371 & 0.374 \\
\hline Panel B: The impact of corrup & on risk tak & the role of & $\left(\boldsymbol{\beta}_{1}+\left(\boldsymbol{\beta}_{1}\right.\right.$ & & & \\
\hline $\boldsymbol{H}_{\mathbf{0}}: \boldsymbol{\beta}_{\mathbf{1}}=\left(\boldsymbol{\beta}_{\mathbf{1}}+\left(\boldsymbol{\beta}_{1} * \boldsymbol{\beta}_{2}\right)\right)$ & $\begin{array}{l}-0.006 \\
(0.054)\end{array}$ & $\begin{array}{l}-0.470 \\
(0.641)\end{array}$ & $\begin{array}{l}-0.021 \\
(0.082)\end{array}$ & $\begin{array}{l}-0.006 \\
(0.075) \\
\end{array}$ & $\begin{array}{l}-0.738 \\
(1.058) \\
\end{array}$ & $\begin{array}{l}-0.601 \\
(1.044) \\
\end{array}$ \\
\hline Panel C: The impact of corrup & on risk tak & the role of & c qualificati & board me & $1+\left(\beta_{1} * \beta\right.$ & \\
\hline$H_{0}: \beta_{1}=\left(\beta_{1}+\left(\beta_{1} * \beta_{3}\right)\right)$ & $\begin{array}{c}-0.044 \\
(1.025) \\
\end{array}$ & $\begin{array}{l}-1.477^{*} \\
(0.864) \\
\end{array}$ & $\begin{array}{l}-0.992 \\
(0.857) \\
\end{array}$ & $\begin{array}{l}-0.982 * \\
(0.541) \\
\end{array}$ & $\begin{array}{l}-0.265 \\
(0.867) \\
\end{array}$ & $\begin{array}{l}-0.108^{*} \\
(0.061) \\
\end{array}$ \\
\hline : The impact of corrt & $\mathrm{n}$ risk t: & he role & tion of $t$ & on bank & $+\left(\beta_{1} * \beta\right.$ & \\
\hline $\boldsymbol{H}_{\mathbf{0}}: \boldsymbol{\beta}_{1}=\left(\boldsymbol{\beta}_{1}+\left(\boldsymbol{\beta}_{1} * \boldsymbol{\beta}_{4}\right)\right)$ & $\begin{array}{l}-0.030 \\
(1.254)\end{array}$ & $\begin{array}{l}-0.100^{*} \\
(0.054)\end{array}$ & $\begin{array}{l}-0.808 \\
(0.557)\end{array}$ & $\begin{array}{l}-0.634 * \\
(0.361)\end{array}$ & $\begin{array}{c}-0.349 \\
(1.280)\end{array}$ & $\begin{array}{l}-0.158 \\
(1.277) \\
\end{array}$ \\
\hline
\end{tabular}


Table 5: Robustness test: Alternative measure of risk

This table reports the results for credit risk models as alternative risk measure. We use Loan loss reserve (LLRs), Non-performing loans (NPLs), and Loan-loss provisions (LLPs) as alternative risk measures. Loan loss reserve is the ratio of loan loss reserves to gross loans. Non-performing loans is the ratio of non-performing loans to gross loans, and Loan-loss provisions is the ratio of loan-loss provisions to average gross loans. $\mathrm{CI}$ is the corruption indicator based on Transparency International's Corruption Perception Index but adjusted by equation (2). Islamic Dummy and the interaction term of Islamic dummy with corruption indicator tests whether the risk-taking of Islamic banks could be differently affected by corruption compared to conventional banks. In all regressions, we use a full set of independent and control variables that include corruption indicator, bank and board characteristics and macroeconomic variables. We only report the coefficients of corruption indicator and its interaction with Islamic dummy for brevity. We apply random effect technique with robust standard errors for our estimations. Robust standard-errors are reported in parentheses. $* * *, * *$, and $*$ indicate significance at $1 \%$, 5\%, and $10 \%$, respectively.

\begin{tabular}{|c|c|c|c|c|c|c|c|c|c|c|c|c|c|c|c|c|c|c|}
\hline \multicolumn{7}{|c|}{ LLRs models } & \multicolumn{6}{|c|}{ NPLs models } & \multicolumn{6}{|c|}{ LLPs models } \\
\hline & \multicolumn{2}{|c|}{ Full Sample } & \multicolumn{2}{|c|}{ Islamic Banks } & \multicolumn{2}{|c|}{ Conventional Banks } & \multicolumn{2}{|c|}{ Full Sample } & \multicolumn{2}{|c|}{ Islamic Banks } & \multicolumn{2}{|c|}{ Conventional Banks } & \multicolumn{2}{|c|}{ Full Sample } & \multicolumn{2}{|c|}{ Islamic Banks } & \multicolumn{2}{|c|}{ Conventional Banks } \\
\hline & (1) & (2) & (3) & (4) & (5) & (6) & (7) & (8) & (9) & (10) & (11) & (12) & (13) & (14) & (15) & (16) & (17) & (18) \\
\hline $\mathrm{CI}\left(\beta_{1}\right)$ & $\begin{array}{l}1.629^{* *} \\
(0.660)\end{array}$ & $\begin{array}{l}1.522 * * \\
(0.634)\end{array}$ & $\begin{array}{c}0.894 * * \\
(0.406)\end{array}$ & $\begin{array}{c}0.775^{* * *} \\
(0.318)\end{array}$ & $\begin{array}{c}2.072 * * * \\
(0.777)\end{array}$ & $\begin{array}{c}2.018^{* * * *} \\
(0.741)\end{array}$ & $\begin{array}{c}0.71 \text { *** } \\
(0.21)\end{array}$ & $\begin{array}{c}0.74 * * \\
(0.33)\end{array}$ & $\begin{array}{c}0.09 * * \\
(0.04)\end{array}$ & $\begin{array}{c}0.10 * * \\
(0.04)\end{array}$ & $\begin{array}{c}0.55^{* * * *} \\
(0.19)\end{array}$ & $\begin{array}{c}0.38^{* * * *} \\
(0.13)\end{array}$ & $\begin{array}{c}1.87^{* * * *} \\
(0.47)\end{array}$ & $\begin{array}{c}1.60^{* * * *} \\
(0.46)\end{array}$ & $\begin{array}{l}1.079 * * \\
(0.428)\end{array}$ & $\begin{array}{l}1.072 * * \\
(0.427)\end{array}$ & $\begin{array}{c}3.280^{* *} \\
(1.476)\end{array}$ & $\begin{array}{c}3.961 * * * \\
(1.166)\end{array}$ \\
\hline Islamic Dummy & $\begin{array}{c}-1.680^{* * * *} \\
(0.240)\end{array}$ & $\begin{array}{c}-0.250 * * * \\
(0.080)\end{array}$ & & & & & $\begin{array}{c}-0.915^{* *} \\
(0.401)\end{array}$ & $\begin{array}{c}-1.014 * * \\
(0.506)\end{array}$ & & & & & $\begin{array}{c}-1.561^{*} \\
(0.915)\end{array}$ & $\begin{array}{l}-1.779^{*} \\
(0.965)\end{array}$ & & & & \\
\hline CIxIslamic Dummy $\left(\beta_{3}\right)$ & $\begin{array}{c}-1.061 * * \\
(0.452)\end{array}$ & $\begin{array}{c}-1.050^{* *} \\
(0.471)\end{array}$ & & & & & $\begin{array}{l}-0.06 * \\
(0.034)\end{array}$ & $\begin{array}{l}-0.07 * * \\
(0.03)\end{array}$ & & & & & $\begin{array}{c}-1.096^{* *} \\
(0.510)\end{array}$ & $\begin{array}{l}-1.04 * \\
(0.590)\end{array}$ & & & & \\
\hline SSBSZ & $\begin{array}{c}-0.144 * * \\
(0.0697)\end{array}$ & $\begin{array}{l}-0.146 * * \\
(0.0697)\end{array}$ & $\begin{array}{c}-2.014 * * \\
(0.995)\end{array}$ & $\begin{array}{l}-2.36 * * \\
(0.973)\end{array}$ & & & $\begin{array}{c}-2.284 * * \\
(0.963)\end{array}$ & $\begin{array}{c}-2.566 * * * \\
(0.852)\end{array}$ & $\begin{array}{c}-0.269 * * \\
(0.114)\end{array}$ & $\begin{array}{c}-0.253 * * \\
(0.121)\end{array}$ & & & $\begin{array}{c}-1.024 * * \\
(0.515)\end{array}$ & $\begin{array}{c}-1.023^{* *} \\
(0.516)\end{array}$ & $\begin{array}{l}-1.432 * \\
(0.778)\end{array}$ & $\begin{array}{c}-0.161^{* *} \\
(0.074)\end{array}$ & & \\
\hline $\operatorname{CI} \times \operatorname{SSBSZ}\left(\beta_{5}\right)$ & $\begin{array}{l}-0.052^{*} \\
(0.029)\end{array}$ & $\begin{array}{l}-0.045^{*} \\
(0.027)\end{array}$ & $\begin{array}{l}-0.368^{*} \\
(0.206)\end{array}$ & $\begin{array}{l}-0.405 \\
(0.304)\end{array}$ & & & $\begin{array}{l}-0.139^{*} \\
(0.0718)\end{array}$ & $\begin{array}{l}-0.144 * * \\
(0.0717)\end{array}$ & $\begin{array}{l}-0.075 \\
(0.050)\end{array}$ & $\begin{array}{l}-0.150^{*} \\
(0.088)\end{array}$ & & & $\begin{array}{l}-0.166^{*} \\
(0.0871)\end{array}$ & $\begin{array}{l}-0.172 * \\
(0.0891)\end{array}$ & $\begin{array}{l}-0.171 * \\
(0.089)\end{array}$ & $\begin{array}{l}-0.169^{*} \\
(0.094)\end{array}$ & & \\
\hline SSBACQ & $\begin{array}{c}-3.095 * * * * \\
(0.897)\end{array}$ & $\begin{array}{c}-3.126 * * * \\
(0.902)\end{array}$ & $\begin{array}{c}-3.27 * * * \\
(1.210)\end{array}$ & $\begin{array}{c}-3.33 * * * \\
(1.22)\end{array}$ & & & $\begin{array}{c}-2.071 * * \\
(0.847)\end{array}$ & $\begin{array}{c}-2.001 * * * \\
(0.666)\end{array}$ & $\begin{array}{c}-3.085^{* * *} \\
(1.371)\end{array}$ & $\begin{array}{c}-3.158 * * \\
(1.329)\end{array}$ & & & $\begin{array}{c}-2.984 * * \\
(1.431)\end{array}$ & $\begin{array}{c}-2.464 * * \\
(1.022)\end{array}$ & $\begin{array}{c}-2.408 * * * \\
(0.602)\end{array}$ & $\begin{array}{c}-1.890^{* *} \\
(0.816)\end{array}$ & & \\
\hline $\operatorname{CI} \times \operatorname{SSBACQ}\left(\beta_{6}\right)$ & $\begin{array}{c}-0.774 * * \\
(0.371)\end{array}$ & $\begin{array}{c}-0.785^{* *} \\
(0.371)\end{array}$ & $\begin{array}{c}-0.120 * * * \\
(0.034)\end{array}$ & $\begin{array}{c}-0.114^{* *} \\
(0.053)\end{array}$ & & & $\begin{array}{l}-0.0216 \\
(0.0137)\end{array}$ & $\begin{array}{l}-0.0227 * \\
(0.0137)\end{array}$ & $\begin{array}{c}-0.487 * * \\
(0.217)\end{array}$ & $\begin{array}{c}-0.513 * * \\
(0.237)\end{array}$ & & & $\begin{array}{l}-0.237 * \\
(0.1308)\end{array}$ & $\begin{array}{c}-0.243^{* *} \\
(0.112)\end{array}$ & $\begin{array}{l}-0.053 * \\
(0.032)\end{array}$ & $\begin{array}{l}-0.047^{*} \\
(0.025)\end{array}$ & & \\
\hline SSBFR & $\begin{array}{c}-2.443^{* *} \\
(1.199)\end{array}$ & $\begin{array}{c}-2.386 * * \\
(1.177)\end{array}$ & $\begin{array}{l}-0.810^{*} \\
(0.475)\end{array}$ & $\begin{array}{c}-0.815^{* * *} \\
(0.372)\end{array}$ & & & $\begin{array}{c}-2.705 * * * \\
(0.571)\end{array}$ & $\begin{array}{c}-2.717 * * * \\
(0.572)\end{array}$ & $\begin{array}{c}-2.94 * * * \\
(0.776)\end{array}$ & $\begin{array}{c}-3.00 * * * \\
(0.791)\end{array}$ & & & $\begin{array}{c}-3.769 * * * \\
(1.067)\end{array}$ & $\begin{array}{c}-2.502^{* *} \\
(1.013)\end{array}$ & $\begin{array}{c}-2.631 * * \\
(1.279)\end{array}$ & $\begin{array}{c}-2.631^{* *} \\
(1.285)\end{array}$ & & \\
\hline CI×SSBFR $\left(\beta_{7}\right)$ & $\begin{array}{l}-0.608^{*} \\
(0.339) \\
\end{array}$ & $\begin{array}{c}-0.606 * * \\
(0.267)\end{array}$ & $\begin{array}{c}-0.063 * * \\
(0.031) \\
\end{array}$ & $\begin{array}{c}-0.066^{* * *} \\
(0.030)\end{array}$ & & & $\begin{array}{l}-1.160 * \\
(0.632)\end{array}$ & $\begin{array}{c}-1.238 * * \\
(0.531) \\
\end{array}$ & $\begin{array}{c}-0.444 * * \\
(0.221) \\
\end{array}$ & $\begin{array}{c}-0.443 * \\
(0.254)\end{array}$ & & & $\begin{array}{l}-0.514 * \\
(0.299) \\
\end{array}$ & $\begin{array}{l}-0.241^{*} \\
(0.139)\end{array}$ & $\begin{array}{l}-0.122 * \\
(0.069)\end{array}$ & $\begin{array}{c}-0.097^{* * *} \\
(0.045)\end{array}$ & & \\
\hline Constant & $\begin{array}{c}3.049 \\
(3.821)\end{array}$ & $\begin{array}{c}7.501 \\
(5.452)\end{array}$ & $\begin{array}{c}6.299 \\
(5.638)\end{array}$ & $\begin{array}{c}6.608 \\
(9.176)\end{array}$ & $\begin{array}{c}0.918 \\
(3.621)\end{array}$ & $\begin{array}{l}9.900^{*} \\
(6.005)\end{array}$ & $\begin{array}{c}10.84 * * * \\
(2.941)\end{array}$ & $\begin{array}{c}10.97 * * * \\
(2.888)\end{array}$ & $\begin{array}{c}7.623 \\
(6.464)\end{array}$ & $\begin{array}{c}7.272 \\
(6.820)\end{array}$ & $\begin{array}{l}-3.696 \\
(2.560)\end{array}$ & $\begin{array}{l}-2.793 \\
(2.535)\end{array}$ & $\begin{array}{l}-14.32 \\
(8.779)\end{array}$ & $\begin{array}{l}-14.73 \\
(9.010)\end{array}$ & $\begin{array}{c}5.846 \\
(3.659)\end{array}$ & $\begin{array}{c}6.005 \\
(3.657)\end{array}$ & $\begin{array}{c}2.137 \\
(1.646)\end{array}$ & $\begin{array}{c}2.418 \\
(1.682)\end{array}$ \\
\hline Year dummies & Yes & Yes & Yes & Yes & Yes & Yes & Yes & Yes & Yes & Yes & Yes & Yes & Yes & Yes & Yes & Yes & Yes & Yes \\
\hline Country dummies & Yes & Yes & Yes & Yes & Yes & Yes & Yes & Yes & Yes & Yes & Yes & Yes & Yes & Yes & Yes & Yes & Yes & Yes \\
\hline Bank controls & Yes & Yes & Yes & Yes & Yes & Yes & Yes & Yes & Yes & Yes & Yes & Yes & Yes & Yes & Yes & Yes & Yes & Yes \\
\hline Country controls & No & Yes & No & Yes & No & Yes & No & Yes & No & Yes & No & Yes & No & Yes & No & Yes & No & Yes \\
\hline Observations & 840 & 840 & 420 & 420 & 420 & 420 & 840 & 840 & 420 & 420 & 420 & 420 & 840 & 840 & 420 & 420 & 420 & 420 \\
\hline Number of Banks & 140 & 140 & 70 & 70 & 70 & 70 & 140 & 140 & 70 & 70 & 70 & 70 & 140 & 140 & 70 & 70 & 70 & 70 \\
\hline R-Squared & 0.165 & 0.177 & 0.242 & 0.244 & 0.307 & 0.319 & 0.356 & 0.381 & 0.412 & 0.408 & 0.327 & 0.295 & 0.178 & 0.181 & 0.258 & 0.261 & 0.294 & 0.302 \\
\hline Panel B: The impact of $\mathrm{c}$ & iption on 1 & taking 0 & $c$ & $\left.\boldsymbol{\beta}_{3}\right)$ & & & & & & & & & & & & & & \\
\hline$H_{0}: \beta_{1}=\left(\beta_{1}+\beta_{3}\right)$ & $\begin{array}{c}0.568 * * \\
(0.241)\end{array}$ & $\begin{array}{c}0.472 * * \\
(0.238)\end{array}$ & & & & & $\begin{array}{c}0.650^{* *} \\
(0.321)\end{array}$ & $\begin{array}{l}0.670^{*} \\
(0.393)\end{array}$ & & & & & $\begin{array}{c}0.774 * * \\
(0.352)\end{array}$ & $\begin{array}{c}0.560^{* * *} \\
(0.266)\end{array}$ & & & & \\
\hline
\end{tabular}


Table 6: Robustness test: Alternative measures of corruption

This table reports the results for alternative measures of corruption. We use Z-score as measure of insolvency risk. Z-score is the inverse of the probability of bank insolvency. Adj.CI and WBCI are the alternative measures of corruption. Islamic Dummy and the interaction term of Islamic dummy with corruption indicator tests whether the risk-taking of Islamic banks could be differently affected by corruption compared to conventional banks. We apply random effect technique with robust standard errors for our estimations. Robust standard-errors are reported in parentheses. $* * *, * *$, and * indicate significance at $1 \%, 5 \%$, and $10 \%$, respectively.

Panel A. The impact of corruption on bank risk

\begin{tabular}{|c|c|c|c|c|c|c|c|c|c|c|c|c|}
\hline \multicolumn{13}{|c|}{ Z-score models } \\
\hline & \multicolumn{4}{|c|}{ Full Sample } & \multicolumn{4}{|c|}{ Islamic Banks } & \multicolumn{4}{|c|}{ Conventional Banks } \\
\hline & (1) & (2) & (3) & (4) & $(5)$ & (6) & (7) & (8) & (9) & (10) & (11) & (12) \\
\hline \multirow[t]{2}{*}{$\operatorname{Adj.CI}\left(\beta_{1}\right)$} & $-3.990 * *$ & $-3.320 * *$ & & & $-1.084 * * *$ & $-1.175^{* *}$ & & & $-3.380 * *$ & $-3.290 * * *$ & & \\
\hline & $(1.584)$ & $(1.340)$ & & & $(0.121)$ & $(0.570)$ & & & $(1.550)$ & $(1.180)$ & & \\
\hline \multirow[t]{2}{*}{$\operatorname{WBCI}\left(\beta_{1}\right)$} & & & $-4.241 * *$ & $-4.541 * *$ & & & $-0.172 * *$ & $-0.145^{* *}$ & & & $-2.892 *$ & $-2.945^{*}$ \\
\hline & & & $(1.720)$ & $(1.947)$ & & & $(0.074)$ & $(0.067)$ & & & (1.736) & $(1.713)$ \\
\hline \multirow[t]{2}{*}{ Islamic Dummy } & $2.467 * *$ & $2.535^{* * *}$ & $2.010^{*}$ & $2.153^{* *}$ & & & & & & & & \\
\hline & $(1.102)$ & $(0.574)$ & $(1.176)$ & $(1.014)$ & & & & & & & & \\
\hline \multirow{2}{*}{ Adj.CI $\times$ Islamic Dummy $\left(\beta_{3}\right)$} & $2.770 * *$ & $2.450 * *$ & & & & & & & & & & \\
\hline & $(1.262)$ & $(1.192)$ & & & & & & & & & & \\
\hline \multirow[t]{2}{*}{ WBCIxIslamic Dummy $\left(\beta_{3}\right)$} & & & $3.207 * *$ & $3.601 * *$ & & & & & & & & \\
\hline & & & $(1.387)$ & $(1.398)$ & & & & & & & & \\
\hline \multirow[t]{2}{*}{ Constant } & $8.910 * *$ & $6.620^{*}$ & $9.900 * *$ & $8.320^{* *}$ & 12.220 & 29.220 & 10.452 & 21.990 & $14.62 * *$ & $12.440^{* *}$ & $18.13 * * *$ & $13.34 * * *$ \\
\hline & $(4.060)$ & $(3.780)$ & $(4.960)$ & $(4.140)$ & (13.070) & $(43.890)$ & $(12.950)$ & $(44.770)$ & $(7.251)$ & $(6.210)$ & $(5.840)$ & $(3.470)$ \\
\hline Bank controls & Yes & Yes & Yes & Yes & Yes & Yes & Yes & Yes & Yes & Yes & Yes & Yes \\
\hline Macroeconomic controls & No & Yes & No & Yes & No & Yes & No & Yes & No & Yes & No & Yes \\
\hline Year dummies & Yes & Yes & Yes & Yes & Yes & Yes & Yes & Yes & Yes & Yes & Yes & Yes \\
\hline Country dummies & Yes & Yes & Yes & Yes & Yes & Yes & Yes & Yes & Yes & Yes & Yes & Yes \\
\hline Observations & 840 & 840 & 840 & 840 & 420 & 420 & 420 & 420 & 420 & 420 & 420 & 420 \\
\hline Number of Banks & 140 & 140 & 140 & 140 & 70 & 70 & 70 & 70 & 70 & 70 & 70 & 70 \\
\hline R-Squared & 0.245 & 0.260 & 0.281 & 0.285 & 0.175 & 0.179 & 0.210 & 0.214 & 0.152 & 0.164 & 0.146 & 0.149 \\
\hline \multicolumn{13}{|c|}{ Panel B: The impact of corruption on risk taking of Islamic bank $\left(\beta_{1}+\beta_{3}\right)$} \\
\hline \multirow[t]{2}{*}{$H_{0}: \beta_{1}=\left(\beta_{1}+\beta_{3}\right)$} & $-1.220^{*}$ & $-0.870^{* *}$ & $-1.034 *$ & $-0.940 * *$ & & & & & & & & \\
\hline & $(0.654)$ & $(0.372)$ & $(0.580)$ & $(0.421)$ & & & & & & & & \\
\hline
\end{tabular}


Table 7: Robustness test: Additional control variables

This table reports the results for robustness test using additional control variables. We use Z-score as measure of insolvency risk. CI is the corruption indicator based on Transparency International's Corruption Perception Index but adjusted by equation (2). Islamic Dummy and the interaction term of Islamic dummy with corruption indicator tests whether the risk-taking of Islamic banks could be differently affected by corruption compared to conventional banks. The institutional variables include; the creditor rights, and the components of economic freedom index (judicial effectiveness, monetary freedom and financial freedom). Four cultural dimensions are also included; individualism (IDV), power distance (PDI), uncertainty avoidance (UAI) and masculinity vs. femininity (MAS). Finally, religiosity is the share of the Muslim population in each country. We apply random effect technique with robust standard errors for our estimations. Robust standard-errors are reported in parentheses. $* * *, * *$, and $*$ indicate significance at $1 \%, 5 \%$, and $10 \%$,

respectively.

\section{Panel A. The impact of corruption on bank risk: Controlling for the institutional environment}

\begin{tabular}{|c|c|c|c|c|c|c|c|c|c|c|c|c|}
\hline \multicolumn{13}{|c|}{ Z-score models } \\
\hline & \multicolumn{4}{|c|}{ Full Sample } & \multicolumn{4}{|c|}{ Islamic Banks } & \multicolumn{4}{|c|}{ Conventional Banks } \\
\hline & (1) & $(2)$ & (3) & (4) & $(5)$ & (6) & (7) & (8) & (9) & (10) & (11) & (12) \\
\hline \multirow[t]{2}{*}{$\overline{\mathrm{CI}\left(\beta_{1}\right)}$} & $-1.012^{* *}$ & $-1.028 * * *$ & $-1.018 * * *$ & $-1.180^{* *}$ & $-1.030^{* *}$ & $-1.260 * * *$ & $-1.160^{*}$ & $-0.910 * *$ & $-1.842 * *$ & $-2.102 * *$ & $-1.980^{* *}$ & $-2.024 * * *$ \\
\hline & $(0.459)$ & $(0.375)$ & $(0.219)$ & $(0.501)$ & $(0.498)$ & $(0.106)$ & $(0.690)$ & $(0.426)$ & $(0.911)$ & $(1.045)$ & $(0.960)$ & $(0.402)$ \\
\hline \multirow[t]{2}{*}{ Islamic Dummy } & $3.183^{* * * *}$ & $3.204 * * *$ & $3.156 * * *$ & $3.541 * * *$ & & & & & & & & \\
\hline & $(0.682)$ & $(0.528)$ & $(0.418)$ & $(0.561)$ & & & & & & & & \\
\hline \multirow[t]{2}{*}{ CI×Islamic Dummy $\left(\beta_{3}\right)$} & $0.321 * *$ & $0.508^{* *}$ & $0.565^{* *}$ & $0.456^{*}$ & & & & & & & & \\
\hline & $(0.134)$ & $(0.219)$ & $(0.241)$ & $(0.251)$ & & & & & & & & \\
\hline Creditor Rights & $\begin{array}{c}0.649 * * * \\
(0.065)\end{array}$ & & & & $\begin{array}{l}0.313 * \\
(0.166)\end{array}$ & & & & $\begin{array}{c}0.055^{* * *} \\
(0.022)\end{array}$ & & & \\
\hline Judicial Effectiveness & & $\begin{array}{l}1.436^{*} \\
(0.805)\end{array}$ & & & & $\begin{array}{c}0.887^{* *} \\
(0.394)\end{array}$ & & & & $\begin{array}{c}0.746^{* * *} \\
(0.205)\end{array}$ & & \\
\hline Monetary Freedom & & & $\begin{array}{c}0.817 * * * \\
(0.154)\end{array}$ & & & & $\begin{array}{c}0.488 * * \\
(0.261)\end{array}$ & & & & $\begin{array}{c}0.126^{*} \\
(0.0713)\end{array}$ & \\
\hline Financial Freedom & & & & $\begin{array}{c}0.256 * * \\
(0.118)\end{array}$ & & & & $\begin{array}{l}0.0174 * \\
(0.0095)\end{array}$ & & & & $\begin{array}{c}0.511 * * \\
(0.241)\end{array}$ \\
\hline Constant & $\begin{array}{c}14.987 * * * \\
(2.161)\end{array}$ & $\begin{array}{c}18.951 * * * \\
(4.960)\end{array}$ & $\begin{array}{c}13.510 * * * \\
(3.141)\end{array}$ & $\begin{array}{c}12.520 * * \\
(4.960)\end{array}$ & $\begin{array}{c}3.852 \\
(4.572)\end{array}$ & $\begin{array}{c}2.615 \\
(5.877)\end{array}$ & $\begin{array}{c}2.596 \\
(3.001)\end{array}$ & $\begin{array}{c}3.010 \\
(4.155)\end{array}$ & $\begin{array}{c}33.050 * * * \\
(9.840)\end{array}$ & $\begin{array}{c}31.650 * * \\
(12.780)\end{array}$ & $\begin{array}{l}27.220^{*} \\
(15.040)\end{array}$ & $\begin{array}{l}29.070 * \\
(17.550)\end{array}$ \\
\hline Bank controls & Yes & Yes & Yes & Yes & Yes & Yes & Yes & Yes & Yes & Yes & Yes & Yes \\
\hline Macroeconomic controls & Yes & Yes & Yes & Yes & Yes & Yes & Yes & Yes & Yes & Yes & Yes & Yes \\
\hline Year dummies & Yes & Yes & Yes & Yes & Yes & Yes & Yes & Yes & Yes & Yes & Yes & Yes \\
\hline Country dummies & Yes & Yes & Yes & Yes & Yes & Yes & Yes & Yes & Yes & Yes & Yes & Yes \\
\hline Observations & 840 & 840 & 840 & 840 & 420 & 420 & 420 & 420 & 420 & 420 & 420 & 420 \\
\hline Number of Banks & 140 & 140 & 140 & 140 & 70 & 70 & 70 & 70 & 70 & 70 & 70 & 70 \\
\hline R-Squared & 0.201 & 0.220 & 0.231 & 0.200 & 0.360 & 0.365 & 0.367 & 0.365 & 0.290 & 0.288 & 0.295 & 0.315 \\
\hline \multicolumn{13}{|c|}{ Panel A.1: The impact of corruption on risk taking of Islamic bank $\left(\beta_{1}+\beta_{3}\right)$} \\
\hline \multirow[t]{2}{*}{$H_{0}: \beta_{1}=\left(\beta_{1}+\beta_{3}\right)$} & $-0.691 * * *$ & $-0.520^{* *}$ & $-0.453^{*}$ & $-0.724 * *$ & & & & & & & & \\
\hline & $(0.105)$ & $(0.249)$ & $(0.257)$ & $(0.310)$ & & & & & & & & \\
\hline
\end{tabular}




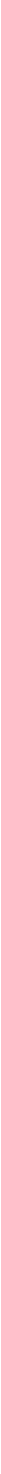


Table 8: Robustness test: Addressing the endogeneity issue

This table reports the results for the relationship between corruption and risk-taking using alternative econometric specifications for the sample of conventional banks, the sample of Islamic banks and the full sample. We use Z-score, the measure of insolvency risk. Z-score is the inverse of the probability of bank insolvency. Regulatory quality is the instrumental variable and refers to as perceptions of the ability of the government to formulate and implement sound policies and regulations that permit and promote private sector development. Lag values of bank risk are also used as instruments but not reported for brevity purpose. $C I$ is the corruption indicator based on Transparency International's Corruption Perception Index but adjusted by equation (2). Robust standard-errors are reported in parentheses. $* * *, * *$, and $*$ indicate significance at $1 \%, 5 \%$, and $10 \%$, respectively.

\begin{tabular}{|c|c|c|c|c|c|c|c|c|c|}
\hline \multicolumn{10}{|c|}{ Panel A: The effect of corruption on bank risk-taking: Baseline results } \\
\hline \multicolumn{10}{|c|}{ Z-score models } \\
\hline & \multicolumn{3}{|c|}{ Conventional Banks } & \multicolumn{3}{|c|}{ Islamic Banks } & \multicolumn{3}{|c|}{ Full Sample } \\
\hline & First stage & 2SLS & GMM & First stage & 2SLS & GMM & First stage & 2SLS & GMM \\
\hline & (1) & (2) & (3) & (4) & (5) & (6) & (7) & (8) & (9) \\
\hline Regulatory quality & $\begin{array}{c}-0.257 * * \\
(0.119)\end{array}$ & & & $\begin{array}{c}-0.141 * * * \\
(0.047)\end{array}$ & & & $\begin{array}{c}-1.454^{* *} \\
(0.590)\end{array}$ & & \\
\hline Z-Score (-1) & $\begin{array}{c}-0.105 * * \\
(0.044)\end{array}$ & & & $\begin{array}{c}-0.421 * * \\
(0.201)\end{array}$ & & & $\begin{array}{c}-0.984 * * * \\
(0.302)\end{array}$ & & \\
\hline Z-Score (-2) & $\begin{array}{l}-0.074 * \\
(0.041)\end{array}$ & & & $\begin{array}{l}-0.215 \\
(0.274)\end{array}$ & & & $\begin{array}{c}-0.516 * * \\
(0.249)\end{array}$ & & \\
\hline $\mathrm{CI}\left(\beta_{1}\right)$ & & $\begin{array}{c}-1.301 * * * \\
(0.452)\end{array}$ & $\begin{array}{c}-1.307 * * * \\
(0.430)\end{array}$ & & $\begin{array}{c}-0.605^{* *} \\
(0.270)\end{array}$ & $\begin{array}{l}-0.502^{*} \\
(0.299)\end{array}$ & & $\begin{array}{c}-1.621 * * * * \\
(0.149)\end{array}$ & $\begin{array}{c}-1.532 * * * * \\
(0.247)\end{array}$ \\
\hline IB_Dummy & & & & & & & & $\begin{array}{c}0.341^{* * * *} \\
(0.105)\end{array}$ & $\begin{array}{c}0.605^{* *} \\
(0.258)\end{array}$ \\
\hline IB_Dummy $\times$ CI $\left(\beta_{3}\right)$ & & & & & & & & $\begin{array}{c}0.172 * * \\
(0.082)\end{array}$ & $\begin{array}{c}0.180 * * \\
(0.076)\end{array}$ \\
\hline \multicolumn{10}{|c|}{ Panel B: The effect of corruption on bank risk-taking: the role of Shari'ah supervision } \\
\hline SSBSZ & & & & & $\begin{array}{l}0.894^{*} \\
(0.508)\end{array}$ & $\begin{array}{l}.052^{* *} \\
(0.536)\end{array}$ & & $\begin{array}{l}1.245^{* * *} \\
(0.492)\end{array}$ & $\begin{array}{l}1.447 * \\
(0.842)\end{array}$ \\
\hline SSBACQ & & & & & $\begin{array}{c}0.217 \\
(0.151)\end{array}$ & $\begin{array}{c}0.556^{* *} \\
(0.224)\end{array}$ & & $\begin{array}{c}0.827 \\
(0.612)\end{array}$ & $\begin{array}{c}0.908 * * \\
(0.411)\end{array}$ \\
\hline SSBFR & & & & & $\begin{array}{c}0.223^{* * * *} \\
(0.049)\end{array}$ & $\begin{array}{c}0.427 * * * \\
(0.036) \\
\end{array}$ & & $\begin{array}{c}0.228 * * * \\
(0.052)\end{array}$ & $\begin{array}{c}0.445^{* * * *} \\
(0.037) \\
\end{array}$ \\
\hline \multicolumn{10}{|c|}{ Panel C: The effect of corruption on bank risk-taking: the role of conventional governance } \\
\hline Board size & & $\begin{array}{c}0.032 \\
(0.189)\end{array}$ & $\begin{array}{c}0.036 \\
(0.188)\end{array}$ & & & & & $\begin{array}{l}1.757^{*} \\
(1.094)\end{array}$ & $\begin{array}{l}1.956^{*} \\
(1.094)\end{array}$ \\
\hline CBACQ & & $\begin{array}{c}-0.219 * * \\
(0.107)\end{array}$ & $\begin{array}{c}-0.207 * * \\
(0.107)\end{array}$ & & & & & $\begin{array}{l}0.023^{*} \\
(0.013)\end{array}$ & $\begin{array}{c}-0.215^{* *} \\
(0.105)\end{array}$ \\
\hline CBFR & & $\begin{array}{c}0.029^{* *} \\
(0.014)\end{array}$ & $\begin{array}{c}0.056^{* * * *} \\
(0.014)\end{array}$ & & & & & $\begin{array}{c}0.022 * * \\
(0.009)\end{array}$ & $\begin{array}{c}0.023 * * * \\
(.009)\end{array}$ \\
\hline Constant & $\begin{array}{c}2.951^{* * *} \\
(1.487)\end{array}$ & $\begin{array}{c}11.148 * * \\
(4.526)\end{array}$ & $\begin{array}{c}11.391 * * \\
(4.563)\end{array}$ & $\begin{array}{l}2.603^{*} \\
(1.380)\end{array}$ & $\begin{array}{c}18.953 * * \\
(9.137)\end{array}$ & $\begin{array}{c}19.103^{* * *} \\
(9.217)\end{array}$ & $\begin{array}{l}3.269^{* *} \\
(1.185)\end{array}$ & $\begin{array}{c}33.352 * * * \\
(0.985)\end{array}$ & $\begin{array}{c}38.495 * * * * \\
(0.972)\end{array}$ \\
\hline Observations & 420 & 420 & 420 & 420 & 420 & 420 & 840 & 840 & 840 \\
\hline Bank controls & Yes & Yes & Yes & Yes & Yes & Yes & Yes & Yes & Yes \\
\hline Macroeconomic controls & Yes & Yes & Yes & Yes & Yes & Yes & Yes & Yes & Yes \\
\hline Country dummies & Yes & Yes & Yes & Yes & Yes & Yes & Yes & Yes & Yes \\
\hline Year dummies & Yes & Yes & Yes & Yes & Yes & Yes & Yes & Yes & Yes \\
\hline Hansen J-stat. (Chi-sq.) & & 0.126 & 0.127 & & 0.526 & 0.521 & & 0.709 & 0.709 \\
\hline Hansen J-stat. (Pro.) & & 0.751 & 0.753 & & 0.882 & 0.882 & & 0.602 & 0.602 \\
\hline KP Wald F-statistics & & $36.710^{* * *}$ & $36.912 * * *$ & & $8.194 * * *$ & $8.230 * * *$ & & $58.270 * * *$ & $58.275^{* * * *}$ \\
\hline \multicolumn{10}{|c|}{ Panel D: The impact of corruption on risk taking of Islamic bank $\left(\beta_{1}+\beta_{3}\right)$} \\
\hline$H_{0}: \beta_{1}=\left(\beta_{1}+\beta_{3}\right)$ & & & & & & & & $\begin{array}{c}-1.449 * * \\
(0.581)\end{array}$ & $\begin{array}{l}-1.352^{*} \\
(0.752)\end{array}$ \\
\hline
\end{tabular}


Table A.1: Sample distribution

This table presents the sample of the study. The study includes 140 banks (70 Islamic and 70 conventional) across ten OIC countries over the period of 2012-2017. The country-wise distribution of the banks, observations, and percentage are given in columns 3-7.

\begin{tabular}{|c|c|c|c|c|c|c|}
\hline Country & Country code & Islamic banks & Conventional banks & Full sample (all banks) & Observations & Percentage (\%) \\
\hline Bahrain & BHR & 11 & 11 & 22 & 132 & 16 \\
\hline Bangladesh & BGD & 8 & 8 & 16 & 96 & 11 \\
\hline Kuwait & KWT & 3 & 3 & 6 & 36 & 4 \\
\hline Lebanon & LBN & 2 & 2 & 4 & 24 & 3 \\
\hline Malaysia & MYS & 14 & 14 & 28 & 168 & 20 \\
\hline Pakistan & PAK & 10 & 10 & 20 & 120 & 14 \\
\hline Saudi Arabia & SAU & 4 & 4 & 8 & 48 & 6 \\
\hline Turkey & TUR & 6 & 6 & 12 & 72 & 9 \\
\hline UAE & ARE & 9 & 9 & 18 & 108 & 13 \\
\hline Yemen & YEM & 3 & 3 & 6 & 36 & 4 \\
\hline Total & & 70 & 70 & 140 & 840 & 100 \\
\hline
\end{tabular}


Table A.2: Pair-wise correlation matrix

This table presents correlations of the different variables used in our analysis.

\begin{tabular}{|c|c|c|c|c|c|c|c|c|c|c|c|c|c|c|c|c|c|c|c|c|c|}
\hline & 1 & 2 & 3 & 4 & 5 & 6 & 7 & 8 & 9 & 10 & 11 & 12 & 13 & 14 & 15 & 16 & 17 & 18 & 19 & 20 & 21 \\
\hline \multicolumn{22}{|l|}{$\overline{\text { Z_Score }}$} \\
\hline Board Size & 0.064 & & & & & & & & & & & & & & & & & & & & \\
\hline Female Ratio & $0.431 * *$ & $0.095 * *$ & & & & & & & & & & & & & & & & & & & \\
\hline Duality & $-0.251 * *$ & $0.074 *$ & 0.061 & & & & & & & & & & & & & & & & & & \\
\hline Audit Committee & 0.041 & $0.204 * *$ & $0.124 * *$ & -0.052 & & & & & & & & & & & & & & & & & \\
\hline Risk Committee & $0.372 *$ & $0.209 * *$ & $0.080^{*}$ & $-0.086^{*}$ & $0.359 * *$ & & & & & & & & & & & & & & & & \\
\hline SSBSZ & $0.371^{* *}$ & $0.072 *$ & $0.217 * *$ & -0.025 & $0.127 * *$ & $0.107^{* *}$ & & & & & & & & & & & & & & & \\
\hline SSBACQ & $0.521 *$ & 0.061 & 0.041 & -0.054 & 0.054 & $0.106^{* *}$ & $0.395^{* *}$ & & & & & & & & & & & & & & \\
\hline SSBFR & $0.610^{* *}$ & -0.025 & $0.171 * *$ & 0.004 & $0.152 * *$ & $0.097^{* *}$ & $0.415^{* *}$ & $0.189^{* *}$ & & & & & & & & & & & & & \\
\hline Assets Growth & 0.025 & $-0.069 *$ & $0.071^{*}$ & 0.017 & 0.001 & -0.041 & -0.024 & $-0.070^{*}$ & 0.052 & & & & & & & & & & & & \\
\hline Bank Size & 0.019 & $-.0128 * *$ & $-0.089 *$ & 0.011 & -0.042 & -0.031 & $-0.131 * *$ & -0.042 & $-0.078^{*}$ & 0.032 & & & & & & & & & & & \\
\hline Capital Ratio & 0.014 & $-0.127^{* *}$ & -0.055 & -0.016 & $0.085^{*}$ & 0.001 & $0.076^{*}$ & 0.024 & 0.043 & 0.035 & 0.001 & & & & & & & & & & \\
\hline Cost Inefficiency & -0.041 & 0.025 & $0.078^{*}$ & 0.022 & 0.044 & $-0.123 * *$ & $0.172 * *$ & 0.023 & $0.160^{* *}$ & -0.051 & 0.019 & -0.014 & & & & & & & & & \\
\hline NII & $-.201 * *$ & -0.044 & -0.042 & -0.027 & 0.047 & $-0.107^{* *}$ & $0.152^{* *}$ & 0.011 & $0.183^{* *}$ & 0.024 & -0.031 & $0.071^{*}$ & $0.196^{* *}$ & & & & & & & & \\
\hline Entry Barrier & 0.061 & 0.058 & 0.015 & 0.061 & 0.042 & $0.078^{*}$ & $0.132^{* *}$ & 0.067 & $0.138^{* *}$ & 0.041 & 0.015 & 0.042 & $0.141^{* *}$ & $0.094 * *$ & & & & & & & \\
\hline Deposit Insurance & -0.014 & -0.029 & $0.189 * *$ & 0.035 & 0.025 & -0.021 & $0.197^{* *}$ & 0.025 & $0.130^{* * *}$ & -0.012 & $-0.078^{*}$ & -0.047 & 0.061 & $0.111 * *$ & $-0.313^{*}$ & & & & & & \\
\hline CI & $-0.523 * *$ & $-0.115^{* *}$ & $-0.136^{*}$ & $0.155^{* *}$ & 0.007 & $-0.090^{*}$ & $0.098^{*}$ & -0.018 & $-0.113^{*}$ & 0.034 & $0.084^{*}$ & 0.002 & $-0.137 *$ & $0.087^{*}$ & 0.061 & $-0.102 *$ & & & & & \\
\hline GDP Growth & 0.045 & $0.191 * *$ & $0.200 * *$ & $0.203^{* *}$ & $0.091 * *$ & $0.107^{* *}$ & 0.061 & 0.061 & $0.136^{* *}$ & 0.014 & $0.117^{*}$ & -0.041 & 0.011 & 0.001 & -0.045 & 0.072 & $0.120^{* *}$ & & & & \\
\hline Supervisory Power & $0.173 *$ & 0.037 & 0.057 & $0.077^{*}$ & 0.067 & $0.110^{* *}$ & 0.055 & 0.069 & 0.017 & 0.007 & $0.074 *$ & $0.114 * *$ & $0.074 *$ & $0.094 * *$ & 0.027 & 0.005 & $0.331^{* *}$ & $0.263 * *$ & & & \\
\hline Oil & 0.029 & -0.051 & $-0.257^{*}$ & $-0.077^{*}$ & $-0.083^{*}$ & $-0.109 * *$ & -0.072 & -0.040 & $-0.211^{*}$ & -0.113 & $0.096^{* *}$ & -0.017 & -0.042 & -0.064 & $0.142 * *$ & $-0.175^{*}$ & $0.389 * *$ & $-0.172 *$ & $-0.282 *$ & & \\
\hline Mineral & 0.055 & -0.017 & $0.218^{* *}$ & $0.187^{* *}$ & $0.080^{*}$ & 0.026 & -0.031 & $-0.134 *$ & $0.106^{* *}$ & $0.126^{* *}$ & -0.044 & 0.012 & $-0.074 *$ & 0.001 & $-0.076^{*}$ & $0.087^{*}$ & $0.132^{* *}$ & $0.227^{* *}$ & -0.018 & $-0.173^{*}$ & \\
\hline
\end{tabular}

*. Correlation is significant at the 0.05 level. 


\section{References}

Abdelbadie, R. A., \& Salama, A. (2019). Corporate governance and financial stability in US banks: Do indirect interlocks matter?. Journal of Business Research, 104, 85-105.

Abdelsalam, O., Dimitropoulos, P., Elnahass, M., \& Leventis, S. (2016). Earnings management behaviors under different monitoring mechanisms: The case of Islamic and conventional banks. Journal of Economic Behavior \& Organization, 132, 155-173.

Abedifar, P., Giudici, P., \& Hashem, S. Q. (2017). Heterogeneous market structure and systemic risk: Evidence from dual banking systems. Journal of Financial Stability, 33, 96-119.

Abedifar, P., Molyneux, P., \& Tarazi, A. (2013). Risk in Islamic banking. Review of Finance. 17, 2035-2096.

Adams, R. B., \& Ferreira, D. (2009). Women in the boardroom and their impact on governance and performance. Journal of financial economics, 94(2), 291-309.

Adhikari, B. K., \& Agrawal, A. (2016). Does local religiosity matter for bank risktaking?. Journal of Corporate Finance, 38, 272-293.

Agoraki, M. E. K., Delis, M. D., \& Pasiouras, F. (2011). Regulations, competition and bank risktaking in transition countries. Journal of Financial Stability, 7(1), 38-48.

Aguilera, R. V., \& Vadera, A. K. (2008). The dark side of authority: Antecedents, mechanisms, and outcomes of organizational corruption. Journal of Business Ethics, 77(4), 431-449.

Ahern, K. R., \& Dittmar, A. K. (2012). The changing of the boards: The impact on firm valuation of mandated female board representation. The quarterly journal of economics, 127(1), 137-197.

Aiyar, M. S., Duval, M. R. A., Puy, M. D., Wu, M. Y., \& Zhang, M. L. (2013). Growth slowdowns and the middle-income trap (No. 13-71). International Monetary Fund.

Alsaadi, A., Ebrahim, M. S., \& Jaafar, A. (2017). Corporate social responsibility, Shariahcompliance, and earnings quality. Journal of financial services research, 51(2), 169-194.

Anderson, R. C., Reeb, D. M., Upadhyay, A., \& Zhao, W. (2011). The economics of director heterogeneity. Financial Management, 40(1), 5-38.

Anginer, D., Bertay, A. C., Cull, R., Demirgüç-Kunt, A., \& Mare, D. S. (2019). Bank Regulation and Supervision Ten Years after the Global Financial Crisis. The World Bank.

Anginer, D., Demirgüç-Kunt, A., \& Mare, D. S. (2018). Bank capital, institutional environment and systemic stability. Journal of Financial Stability, 37, 97-106.

Anginer, D., Demirguc-Kunt, A., \& Zhu, M. (2014). How does competition affect bank systemic risk?. Journal of Financial Intermediation, 23(1), 1-26.

Anginer, D., Demirguc-Kunt, A., \& Zhu, M. (2014). How does deposit insurance affect bank risk? Evidence from the recent crisis. Journal of Banking \& Finance, 48, 312-321.

Ashraf, B. N., \& Arshad, S. (2017). Foreign bank subsidiaries' risk-taking behavior: Impact of home and host country national culture. Research in International Business and Finance, 41, 318-335.

Ashraf, B. N., Zheng, C., \& Arshad, S. (2016). Effects of national culture on bank risk-taking behavior. Research in International Business and Finance, 37, 309-326.

Baele, L., Farooq, M., \& Ongena, S. (2014). Of religion and redemption: Evidence from default on Islamic loans. Journal of Banking \& Finance, 44, 141-159.

Barth, J. R., Lin, C., Lin, P., \& Song, F. M. (2009). Corruption in bank lending to firms: crosscountry micro evidence on the beneficial role of competition and information sharing. Journal of Financial Economics, 91(3), 361-388. 
Barth, J. R., Lin, C., Ma, Y., Seade, J., \& Song, F. M. (2013). Do bank regulation, supervision and monitoring enhance or impede bank efficiency?. Journal of Banking \& Finance, 37(8), 2879-2892.

Beck T, Demirgüç-Kunt A, Merrouche O. (2013). Islamic vs conventional banking: business model, efficiency and stability. Journal of Banking Finance, 37, 433-447

Beckman, C. M., \& Haunschild, P. R. (2002). Network learning: The effects of partners' heterogeneity of experience on corporate acquisitions. Administrative science quarterly, 47(1), 92-124.

Berger, A. N., Kick, T., \& Schaeck, K. (2014). Executive board composition and bank risk taking. Journal of Corporate Finance, 28, 48-65.

Berger, A. N., Li, X., Morris, C. S., \& Roman, R. A. (2021). The effects of cultural values on bank failures around the world. Journal of Financial and Quantitative Analysis, 56(3), 945993.

Bermpei, T., Kalyvas, A. N., \& Leonida, L. (2020). Local Public Corruption and Bank Lending Activity in the United States. Journal of Business Ethics, 1-26.

Bitar, M., \& Tarazi, A. (2019). Creditor rights and bank capital decisions: Conventional vs. Islamic banking. Journal of Corporate Finance, 55, 69-104.

Bitar, M., Ben Naceur, S., Ayadi, R., Walker, T. (2020), "Basel compliance and financial stability: Evidence from Islamic banks", Journal of Financial Services Research, forthcoming 2020.

Bitar, M., Hassan, M. K., \& Hippler, W. J. (2018). The determinants of Islamic bank capital decisions. Emerging Markets Review, 35, 48-68.

Bitar, M., Hassan, M. K., Saad, W. (2020), Culture and the capital-performance nexus in dual banking systems. Economic Modelling, Vol. 87.

Blanc, R., Cho, C. H., Sopt, J., \& Branco, M. C. (2019). Disclosure responses to a corruption scandal: The case of Siemens AG. Journal of Business Ethics, 156(2), 545-561.

Blau, B. M. (2017). Religiosity and the volatility of stock prices: A cross-country analysis. Journal of Business Ethics, 144(3), 609-621.

Bostandzic, D., \& Weiss, G. N. (2018). Why do some banks contribute more to global systemic risk?. Journal of Financial Intermediation, 35, 17-40.

Boubakri, N., Mirzaei, A., \& Samet, A. (2017). National culture and bank performance: Evidence from the recent financial crisis. Journal of Financial Stability, 29, 36-56.

Brown, N. C., Smith, J. D., White, R. M., \& Zutter, C. J. (2019). Political corruption and firm value in the US: Do rents and monitoring matter? Journal of Business Ethics, 1-17.

Cai, G., Li, W., \& Tang, Z. (2020). Religion and the method of earnings management: Evidence from China. Journal of Business Ethics, 161(1), 71-90.

Campbell, K., \& Mínguez-Vera, A. (2008). Gender diversity in the boardroom and firm financial performance. Journal of business ethics, 83(3), 435-451.

Carter, D. A., D'Souza, F., Simkins, B. J., \& Simpson, W. G. (2010). The gender and ethnic diversity of US boards and board committees and firm financial performance. Corporate Governance: An International Review, 18(5), 396-414.

Chantziaras, A., Dedoulis, E., Grougiou, V., \& Leventis, S. (2020). The impact of religiosity and corruption on CSR reporting: The case of US banks. Journal of Business Research, 109, 362374.

Chapple, L., \& Humphrey, J. E. (2014). Does board gender diversity have a financial impact? Evidence using stock portfolio performance. Journal of business ethics, 122(4), 709-723. 
Charumilind, C., Kali, R., \& Wiwattanakantang, Y. (2006). Connected lending: Thailand before the financial crisis. The Journal of Business, 79(1), 181-218.

Chen, H., Huang, H. H., Lobo, G. J., \& Wang, C. (2016). Religiosity and the cost of debt. Journal of Banking \& Finance, 70, 70-85.

Chen, M., Jeon, B. N., Wang, R., \& Wu, J. (2015). Corruption and bank risk-taking: Evidence from emerging economies. Emerging Markets Review, 24, 122-148.

Chen, Y., Liu, M., \& Su, J. (2013). Greasing the wheels of bank lending: Evidence from private firms in China. Journal of Banking \& Finance, 37(7), 2533-2545.

Chircop, J., Fabrizi, M., Ipino, E., \& Parbonetti, A. (2017). Does branch religiosity influence bank risk-taking?. Journal of Business Finance \& Accounting, 44(1-2), 271-294.

Choudhury, M. A., \& Alam, M. N. (2013). Corporate governance in Islamic perspective. International journal of Islamic and Middle Eastern finance and management.

Daily, C. M., \& Dalton, D. R. (2003). Women in the boardroom: A business imperative. Journal of Business strategy.

Dang, R., Bender, A. F., and Scotto, M. J. (2014). Women on French corporate board of directors: How do they differ from their male counterparts? Journal of Applied Business Research, 30(2): 489-507.

DeBacker, J., Heim, B. T., \& Tran, A. (2015). Importing corruption culture from overseas: Evidence from corporate tax evasion in the United States. Journal of Financial Economics, 117(1), 122-138.

Dela Rama, M. (2012). Corporate governance and corruption: Ethical dilemmas of Asian business groups. Journal of Business Ethics, 109(4), 501-519.

Detragiache, E., P. Gupta, T. Tressel, (2008). Foreign banks in poor countries: Theory and evidence. Journal of Finance, 63(5), 2123-2160.

Djankov, S., McLiesh, C., \& Shleifer, A. (2007). Private credit in 129 countries. Journal of financial Economics, 84(2), 299-329.

Elamer, A. A., Ntim, C. G., Abdou, H. A., \& Pyke, C. (2020). Sharia supervisory boards, governance structures and operational risk disclosures: Evidence from Islamic banks in MENA countries. Global Finance Journal, 46, 100488.

Faleye, O., \& Krishnan, K. (2017). Risky lending: does bank corporate governance matter?. Journal of Banking \& Finance, 83, 57-69.

Fan, Y., Jiang, Y., Zhang, X., \& Zhou, Y. (2019). Women on boards and bank earnings management: From zero to hero. Journal of Banking \& Finance, 107, 105607.

Farag, H., Mallin, C., \& Ow-Yong, K. (2018). Corporate governance in Islamic banks: New insights for dual board structure and agency relationships. Journal of International Financial Markets, Institutions and Money, 54, 59-77.

Ferreira, D. (2015). Board diversity: Should we trust research to inform policy? Corporate Governance: An International Review, 23(2): 108-111.

Francis, B., Hasan, I., \& Wu, Q. (2015). Professors in the boardroom and their impact on corporate governance and firm performance. Financial management, 44(3), 547-581.

Fratzscher, M., \& Rieth, M. (2019). Monetary policy, bank bailouts and the sovereign-bank risk nexus in the euro area. Review of Finance, 23(4), 745-775.

$\mathrm{Fu}, \mathrm{Y}$. (2019). The value of corporate governance: Evidence from the Chinese anti-corruption campaign. The North American Journal of Economics and Finance, 47, 461-476.

Gaganis, C., Hasan, I., Papadimitri, P., \& Tasiou, M. (2019). National culture and risk-taking: Evidence from the insurance industry. Journal of Business Research, 97, 104-116. 
Gan, W., \& Xu, X. (2019). Does anti-corruption campaign promote corporate R\&D investment? Evidence from China. Finance Research Letters, 30, 292-296.

García-Sánchez, I. M., García-Meca, E., \& Cuadrado-Ballesteros, B. (2017). Do financial experts on audit committees matter for bank insolvency risk-taking? The monitoring role of bank regulation and ethical policy. Journal of Business Research, 76, 52-66.

Gorsira, M., Denkers, A., \& Huisman, W. (2018). Both sides of the coin: Motives for corruption among public officials and business employees. Journal of Business Ethics, 151(1), 179-194.

Goyeau, D., \& Tarazi, A. (1992). An empirical investigation on bank risk in Europe. International Finance Group Working Paper 93-11, the University of Birmingham.

Green, C. P., \& Homroy, S. (2018). Female directors, board committees and firm performance. European Economic Review, 102, 19-38.

Gu, X., Kadiyala, P., \& Mahaney-Walter, X. W. (2018). How creditor rights affect the issuance of public debt: The role of credit ratings. Journal of Financial Stability, 39, 133-143.

Guney, Y., Karpuz, A., \& Komba, G. (2020). The effects of board structure on corporate performance: Evidence from East African frontier markets. Research in International Business and Finance, 53, 101222.

Hanousek, J., Shamshur, A., \& Tresl, J. (2019). Firm efficiency, foreign ownership and CEO gender in corrupt environments. Journal of Corporate Finance, 59, 344-360.

Hofstede, G. (1980). Culture and organizations. International studies of management \& organization, 10(4), 15-41.

Hofstede, G. (2001). Culture's recent consequences: Using dimension scores in theory and research. International Journal of cross cultural management, 1(1), 11-17.

Houston, J. F., Lin, C., Lin, P., \& Ma, Y. (2010). Creditor rights, information sharing, and bank risk taking. Journal of financial Economics, 96(3), 485-512.

Jha, C. K., \& Sarangi, S. (2018). Women and corruption: What positions must they hold to make a difference?. Journal of Economic Behavior \& Organization, 151, 219-233.

Joseph, C., Gunawan, J., Sawani, Y., Rahmat, M., Noyem, J. A., \& Darus, F. (2016). A comparative study of anti-corruption practice disclosure among Malaysian and Indonesian Corporate Social Responsibility (CSR) best practice companies. Journal of cleaner production, 112, 2896-2906.

Kabir, M. N., Worthington, A., \& Gupta, R. (2015). Comparative credit risk in Islamic and conventional bank. Pacific-Basin Finance Journal, 34, 327-353.

Kanagaretnam, K., Lim, C.Y., \& Lobo, G.J. (2011). Effects of national culture on earnings quality of banks. Journal of International Business Studies, 42, 853-874.

Kanagaretnam, K., Lobo, G. J., \& Wang, C. (2015). Religiosity and earnings management: International evidence from the banking industry. Journal of Business Ethics, 132(2), 277296.

Karimalis, E. N., \& Nomikos, N. K. (2018). Measuring systemic risk in the European banking sector: A Copula CoVaR approach. The European Journal of Finance, 24(11), 944-975.

Khan, M. H., Fraz, A., Hassan, A., \& Abedifar, P. (2020). Female board representation, risktaking and performance: Evidence from dual banking systems. Finance Research Letters, 37, 101541.

Khan, M. S., Scheule, H., \& Wu, E. (2017). Funding liquidity and bank risk taking. Journal of Banking \& Finance, 82, 203-216.

Khwaja, A. I., \& Mian, A. (2005). Do lenders favor politically connected firms? Rent provision in an emerging financial market. The Quarterly Journal of Economics, 120(4), 1371-1411. 
King, T., Srivastav, A., \& Williams, J. (2016). What's in an education? Implications of CEO education for bank performance. Journal of Corporate Finance, 37, 287-308.

Laeven, L., \& Levine, R. (2009). Bank governance, regulation and risk taking. Journal of financial economics, 93(2), 259-275.

Lambsdorff, J. G. (2008). The methodology of the corruption perceptions index. Transparency International and University of Passau, Germany. http://www. transparency. org/policy_research/surveys_indices/cpi.

Lee, Y. J., Yoon, H. J., \& O'Donnell, N. H. (2018). The effects of information cues on perceived legitimacy of companies that promote corporate social responsibility initiatives on social networking sites. Journal of business research, 83, 202-214.

Li, K., Griffin, D., Yue, H., \& Zhao, L. (2013). How does culture influence corporate risktaking? Journal of Corporate Finance, 23, 1-22.

Liu, Y., Wei, Z., \& Xie, F. (2014). Do women directors improve firm performance in China?. Journal of corporate finance, 28, 169-184.

Lombardi, R., Trequattrini, R., Cuozzo, B., \& Cano-Rubio, M. (2019). Corporate corruption prevention, sustainable governance and legislation: First exploratory evidence from the Italian scenario. Journal of Cleaner Production, 217, 666-675.

Meslier, C., Risfandy, T., \& Tarazi, A. (2017). Dual market competition and deposit rate setting in Islamic and conventional banks. Economic Modelling, 63, 318-333.

Mollah, S., \& Zaman, M. (2015). Shari'ah supervision, corporate governance and performance: Conventional vs. Islamic banks. Journal of Banking \& Finance, 58, 418-435.

Mollah, S., Hassan, M. K., Al Farooque, O., \& Mobarek, A. (2017). The governance, risk-taking, and performance of Islamic banks. Journal of financial services research, 51(2), 195-219.

Mourouzidou-Damtsa, S., Milidonis, A., \& Stathopoulos, K. (2019). National culture and bank risk-taking. Journal of Financial Stability, 40, 132-143.

Nawaz, T. (2019). Exploring the nexus between human capital, corporate governance and performance: Evidence from Islamic Banks. Journal of Business Ethics, 157(2), 567-587.

Palvia, A., Vähämaa, E., \& Vähämaa, S. (2015). Are female CEOs and chairwomen more conservative and risk averse? Evidence from the banking industry during the financial crisis. Journal of Business Ethics, 131(3), 577-594.

Pan, X., \& Tian, G. G. (2017). Political connections and corporate investments: Evidence from the recent anti-corruption campaign in China. Journal of Banking \& Finance, 105108.

Park, J. (2012). Corruption, soundness of the banking sector, and economic growth: A crosscountry study. Journal of international money and Finance, 31(5), 907-929.

Pew Research Center., 2015. Muslims and Islam: Key findings in the U.S. and around the world, retrieved from: http://www.pewresearch.org/fact-tank/2017/08/09/muslims-and-islam-keyfindings-in-the-u-s-and-around-the-world/

Pok, W. C. (2012). Analysis of Shariah quantitative screening norms among Malaysia Shariahcompliant stocks. Investment Management and Financial Innovations, 9(2), 69-80.

Post, C., \& Byron, K. (2015). Women on boards and firm financial performance: A metaanalysis. Academy of management Journal, 58(5), 1546-1571.

Razak, N. (2011). The 2012 budget speech, Prime Minister Office. Retrieved from: http://www.pmo.gov.my/?menu=speech\&page=1676\&speech_cat=2\&news id=529.

Robinson, G., \& Dechant, K. (1997). Building a business case for diversity. Academy of Management Perspectives, 11(3), 21-31. 
Roy, A. D. (1952). Safety first and the holding of assets. Econometrica: Journal of the econometric society, 431-449.

Safiullah, M., \& Shamsuddin, A. (2018). Risk in Islamic banking and corporate governance. Pacific-Basin Finance Journal, 47, 129-149.

Safiullah, M., \& Shamsuddin, A. (2019). Risk-adjusted efficiency and corporate governance: Evidence from Islamic and conventional banks. Journal of Corporate Finance, 55, 105-140.

Salem, R., Usman, M., \& Ezeani, E. (2021). Loan loss provisions and audit quality: Evidence from MENA Islamic and conventional banks. The Quarterly Review of Economics and Finance, 79, 345-359.

Sartor, M. A., \& Beamish, P. W. (2019). Private Sector Corruption, Public Sector Corruption and the Organizational Structure of Foreign Subsidiaries. Journal of Business Ethics, 1-20.

Semykina, A., \& Wooldridge, J. M. (2010). Estimating panel data models in the presence of endogeneity and selection. Journal of Econometrics, 157(2), 375-380.

Sena, V., Duygun, M., Lubrano, G., Marra, M., \& Shaban, M. (2018). Board independence, corruption and innovation. Some evidence on UK subsidiaries. Journal of Corporate Finance, $50,22-43$.

Sila, V., Gonzalez, A., \& Hagendorff, J. (2016). Women on board: Does boardroom gender diversity affect firm risk?. Journal of Corporate Finance, 36, 26-53.

Srivastav, A., \& Hagendorff, J. (2016). Corporate governance and bank risk-taking. Corporate Governance: An International Review, 24(3), 334-345.

Terjesen, S., Couto, E. B., \& Francisco, P. M. (2016). Does the presence of independent and female directors impact firm performance? A multi-country study of board diversity. Journal of Management \& Governance, 20(3), 447-483.

Thakur, B. P. S., \& Kannadhasan, M. (2019). Corruption and cash holdings: Evidence from emerging market economies. Emerging Markets Review, 38, 1-17.

Van Vu, H., Tran, T. Q., Van Nguyen, T., \& Lim, S. (2018). Corruption, types of corruption and firm financial performance: New evidence from a transitional economy. Journal of Business Ethics, 148(4), 847-858.

Weill, L. (2011). How corruption affects bank lending in Russia. Economic systems, 35(2), 230243.

Wellalage, N. H., Locke, S., \& Samujh, H. (2019). Corruption, gender and credit constraints: Evidence from South Asian SMEs. Journal of Business Ethics, 159(1), 267-280.

Williams, C. C., \& Martinez-Perez, A. (2016). Evaluating the impacts of corruption on firm performance in developing economies: An institutional perspective. International Journal of Business and Globalization, 16(4), 401-422.

Williams, C. C., Martinez-Perez, A., \& Kedir, A. (2016). Does bribery have a negative impact on firm performance? A firm-level analysis across 132 developing countries. International Journal of Entrepreneurial Behavior \& Research. 